\title{
1 Prediction of the depth-averaged two-dimensional flow direction 2 along a meander in compound channels
}

4 Yuqi Shan ${ }^{1,2}$, Sheng Huang ${ }^{3}$, Chao Liu ${ }^{2,3^{*}}$, Yakun Guo ${ }^{4}$, Kejun Yang ${ }^{3}$ 5

6 1. College of Applied Mathematics, Chengdu University of Information Technology, Chengdu 7 610225, China

8 2. Department of Civil and Environmental Engineering, Massachusetts Institute of Technology, 9 Cambridge, MA 02139, USA

10 3. State Key Laboratory of Hydraulics and Mountain River Engineering, Sichuan University, 11 Chengdu 610065, China

12 4. School of Engineering, University of Bradford, BD7 1DP, UK

14 *Corresponding author:

15 Chao Liu, Email: chaoliu@ @scu.edu.cn; chaoliu@mit.edu

17 Highlights:

18 (1) The flow direction is predicted along a meander in smooth and vegetated compound channels.

19 (2) The influence of floodplain vegetation on the height of the secondary current cell is evaluated.

20 (3) The dominant factors affecting the depth-averaged flow angle along a meander are 21 investigated.

22 (4) Predictions are verified using flume and field measurements from different sources. 
23 Abstract: For overbank flows in meandering channels, the flow direction along a meander varies

24 and is affected by floodplain vegetation. This study proposes a model for predicting the

25 depth-averaged two-dimensional flow direction (depth-averaged flow angle) along a meander in

26 smooth and vegetated meandering compound channels. Laboratory experiments were performed

27 in smooth and vegetated channels. Measurements show that the height of the secondary current

28 cell in the main channel is increased by dense floodplain vegetation comparing with that in a

29 non-vegetated channel. A method of determining the height of the cell is proposed. At the middle

30 section between the apex and exit sections, where the secondary current cell is absent, the

31 depth-averaged flow angle is independent of the height of the cell. Beyond the middle section, a

32 new secondary current cell is formed, and the flow angle is highly dependent on the height of the

33 cell. The proposed model is thoroughly verified using the flume experimental and field observed

34 data. Good agreement is obtained between predictions and measurements, indicating that the

35 proposed model is capable of accurately predicting the depth-averaged flow angle along a

36 meander in smooth and vegetated meandering compound channels.

37

38 Keywords: predictive model, depth-averaged flow angle, vegetation, meandering compound

39 channel, secondary current cell 


\section{Introduction}

Natural rivers exhibit a meandering shape that is influenced by sediment transport and bed erosion.

Throughout most of the year, upstream discharge is small, which results in the inbank case in which

water flows downstream in the meandering main channel (Shiono and Muto 1998; Keevil et al. 2006;

Wang et al. 2009). The floodplains on both sides of the main channel are ideal locations for vegetation

because the water source is close (Gunawan et al. 2005; Yang et al. 2007). During a flood period, the

upstream discharge increases, and the flow depths in the main channel and floodplains increase.

Therefore, the floodplains and vegetation are inundated, and a meandering compound channel forms.

The presence of floodplain vegetation enhances flow resistance on the floodplain and thus decreases

the channel conveyance capability. For example, Liu et al. (2016a) found that the conveyance

capability of a smooth compound channel was $30 \%$ greater than that of a compound channel with

submerged dense vegetation for an identical flow depth. Based on this result and considering the same

upstream flood discharge, the flow depth in a vegetated channel must be greater than that in a

non-vegetated channel, which increases the risk of flood disasters (Liu et al. 2016b; Shan et al. 2017).

A secondary current cell is a typical feature in a meandering compound channel (Shiono and Muto

1998; Shiono et al. 2009; Liu et al. 2016a). The generation mechanism of secondary current cells 
causes the cells to vary along a meander. Specifically, a secondary current cell in a meandering main channel consists of an enhanced original secondary current cell, which is strengthened by centrifugal force, and a component of the upstream floodplain flow, which is highly related to the floodplain roughness (smooth or vegetated floodplains). Liu et al. (2016a) reported that with the same flow depth, a secondary current cell at the apex section (e.g. CS1 in Figure 1) in a vegetated meandering compound channel is stronger than that in a smooth channel. This is because the floodplain vegetation decreases the floodplain mean velocity and increases the mean velocity in the main channel, producing a high centrifugal force and leading to the formation of strong secondary current cells. Notably, at the apex section (e.g. CS1 and 7 in Figure 1), the main channel flow and floodplain flow have the same flow direction; thus, the influence of the floodplain vegetation on a secondary current cell in the main channel is negligible. In contrast, at the crossover section (e.g. CS4 in Figure 1), the secondary current cell in a vegetated channel is weaker than that in a smooth channel because floodplain vegetation decreases the floodplain mean velocity and consequently decreases the contribution of the upstream floodplain flow on the secondary current cell of the main channel. In addition, a new secondary current cell forms at the exit section of a meander bend (CS3), and it gradually develops as the section proceeds (Shiono and Muto 1998; Liu et al. 2014, 2016a). Between the entrance section (CS5) and 
apex section (CS7) of the next meander bend, the width of the secondary current cell is nearly the same as the channel width, indicating that the cell is fully developed in the lateral direction. This property has been demonstrated by flume experiments (Liu et al. 2016a) and numerical simulations (Jing et al. 2009).

The prediction of the depth-averaged two-dimensional flow direction (depth-averaged flow angle) is highly related to the secondary current cell. Liu et al. (2018a) linked the depth-averaged flow angle to a secondary current cell and proposed a model for predicting the depth-averaged flow angle.

However, the model of Liu et al. is valid only between the entrance section (CS5) and apex section (CS7), where the secondary current cell is fully developed in the lateral direction and occupies the most of the section. As afore-discussed, a new secondary current cell is formed at the exit section (CS3) and is not fully developed in the lateral direction until the next entrance section (CS5). A valid model for predicting the depth-averaged flow angle beyond the apex section does not currently exist. In addition, floodplain vegetation can alter the depth-averaged flow angle along a meander, but the influence of the vegetation on secondary current cells is still unclear. Moreover, no model exists for predicting the flow angle along a meander in a vegetated channel.

For depth-averaged two-dimensional numerical models, the plan form of the depth-averaged 
velocity is normally used to express the velocity magnitude and flow direction (Wu et al. 2004; Ismail 2007; Harrison et al. 2015; Ding et al. 2017). In meandering channels, inaccurate prediction of flow direction may produce inaccurate velocity magnitudes because the flow direction is related to the depth-averaged streamwise velocity, which is in turn related to the conveyance capability, and the depth-averaged lateral velocity, which is related to the secondary current cells (Chen et al. 2015). The prediction of the depth-averaged flow angle can provide a reference for verifying numerical simulation. For example, Ismail (2007) modeled the depth-averaged velocity in a meandering compound channel with a relative flow depth of $D r=0.45$, where $D r=\frac{H-h}{H}$ based on the flow depth $H$ and bankfull level $h$. At the entrance and apex sections, the modeled depth-averaged flow angles agree well with the predicted values based on the model of Liu et al. (2018a). This result indicates that Ismail's model could also precisely estimate streamwise and lateral velocities. Being consistent with this finding, the modeled streamwise velocities and secondary flows are nearly the same as the measured values (see discussion in Ismail 2007). However, to our best knowledge, there has not been a report on numerical simulations in a vegetated meandering compound channel. The numerical modeling of a meandering channel with these characteristics is challenging because the presence of floodplain vegetation produces extra resistance (Shiono et al. 2009; Liu et al. 2016a) and additional turbulence (Liu and Nepf 
2016; Liu et al. 2018b), which makes the simulation more difficult compared to simulating smooth channels.

Furthermore, the depth-averaged flow angle can be linked to the main channel flow

discharge/velocity in meandering compound channels. For example, Liu et al. (2018a) found that along

a meander, the apex section (CS1 or CS7) with the smallest depth-averaged flow angle $\left(\approx 0^{\circ}\right)$ has the largest flow discharge; while the section between exit section (CS3) and entrance section (CS5) with the largest depth-averaged flow angle has the smallest flow discharge (see Figure 9 in Liu et al. 2018a). The connection between the depth-averaged flow angle and main channel flow discharge/velocity can provide insights in understanding the change in bed morphology because sediment motion is highly related to flow velocity. Bed erosion and deposition could occur in the apex section (CS1) and the section between CS3 and CS5, respectively, based on the flow discharge distribution along a meander. Lyness et al. (2001) performed an experiment in a meandering channel with a mobile main channel and roughed floodplains. In the meandering main channel, they observed a scour area at the apex sections and a deposition area between the exit and entrance sections (see Figure 10b in Lyness et al. 2001). Therefore, the depth-averaged flow angle can be a tool to evaluate the change in flow discharge along a meandering main channel and in turn to estimate the local change in bed morphology. 
The goal of this paper is to propose a model for predicting the depth-averaged flow direction along an entire meander (CS1 to CS7) in smooth and vegetated compound channels, which is different from the previous study (Liu et al. 2018a), in which the flow direction was only predicted in the sections (CS5 to CS7) with fully developed secondary current cells. The arrangement of the paper is as following. A series of experiments is described in Section 2. Data collected from the published literature used for model validation are introduced in Section 3. Section 4 describes the influence of dense vegetation on the height of a secondary current cell in a meandering main channel. Section 5 describes the theory of the predictive model. The results and discussions are given in Sections 6 and 7, respectively. Finally, Section 8 provides a summary of this study.

\section{Flume experiments}

To discuss the influence of dense floodplain vegetation on the secondary current cell of a

meandering main channel, three cases (MN1-MN3) were studied in a smooth meandering compound channel (Liu et al. 2014; Shan et al. 2015). Then, three further cases (MV1-MV3) were investigated in the same meandering compound channel, but vegetation was affixed on all parts of the floodplains (Liu et al. 2016a). For convenience, MN1 to MN3 are deemed smooth cases, and MV1 to MV3 are deemed 
vegetated cases.

Experiments were performed in a 35 m-long, 4 m-wide and $1 \mathrm{~m}$-high flume with overbank flows.

A triangular weir at the beginning of the flume was used to measure the channel discharge $(Q)$. The

main channel flow depth $(H)$ was 0.188 to $0.256 \mathrm{~m}$, so that the relative flow depth, $D r$, was 0.26 to 0.45

in both the smooth and vegetated channels. The width of the meandering main channel $(b)$ was $0.7 \mathrm{~m}$,

and the bankfull level $(h)$ was $0.14 \mathrm{~m}$, yielding an aspect ratio of $b / h=5$. The sinuosity of the

meandering main channel $(s)$ was defined as the ratio of the wavelength $\left(L_{w}\right)$ to the valley length $\left(L_{v}\right)$ in

half a meander, i.e., $s=L_{w} / L_{v}$. This definition is the same as that used in published studies (see Section

3). In this study, $s=1.38$, which was chosen based on the sinuosity of natural rivers $(s=1.3$ to 1.5 , as

reported by Wormleaton et al. 2004). The valley slope $(S)$ was $1 \%$, and the slope of the meandering

main channel $\left(S_{m c}\right)$ was $S / s(=0.7 \%)$. The inner radius of the meander bend $(r)$ was $0.9 \mathrm{~m}$. The channel

surface, including the vertical walls of the meandering main channel and the vertical walls of

floodplains, was smoothed using concrete, which produced a Manning's roughness $(n)$ value of 0.015.

Fully developed flow was achieved in the experiments because the Reynolds number varied from $R e$

$\approx 15000$ to 42000 . Specifically, $R e=\frac{Q R}{A v}$, where $A$ is the cross-sectional area at an apection, $R$ is the hydraulic radius at the apex section, and $v$ is the kinematic viscosity. A tailgate at the end of the flume 
was manually modified to ensure that the slope of the water surface was parallel to the valley slope and achieve quasi-uniform flow conditions. The experimental parameters are summarized in Table 1.

Along half a meander, the section angle $\left(\theta_{x}\right)$ was $0^{\circ}$ for apex sections (CS1 and CS7), $30^{\circ}$ for the two middle sections (CS2 and CS6), and $60^{\circ}$ between the exit and entrance sections (CS3, CS4 and CS5). For a meander bend, the geometrical angle $\left(\theta_{\text {geo }}\right)$ between the entrance section (CS5) and apex section (CS7) was $60^{\circ}$. The plan view of sections is shown in Figure 1. The flow structure was periodic along a meander. Thus, the depth-averaged flow angle exhibited the same pattern along each half meander (CS1 to CS7). The measurements of three-dimensional velocity were performed at CS1 to CS7. At each section, 13 measurement lines were arranged in the meandering main channel with a lateral interval of $5 \mathrm{~cm}$ that was the same in all cases. Because a Sontek Acoustic Doppler Velocimeter (ADV) has a blind spot of $5 \mathrm{~cm}$, an ADV with a down-looking probe and an up-looking probe was used to cover the blind spot and record the velocity at all points along a measurement line. The sample recording frequency and duration were $50 \mathrm{~Hz}$ and $30 \mathrm{~s}$, respectively. Liu et al. (2016b) and Shan et al. (2017) demonstrated that the number of recordings at each point was sufficient to obtain accurate time-averaged velocities. The raw velocity data were de-spiked using the method of Goring and Nikora (2002). Then, the processed data were used to calculate the time-averaged velocities $(U, V$ and $W)$ in 
the streamwise, lateral and vertical directions. Based on these results, the local flow direction $\theta(z)$ $\left(=\arctan \frac{V}{U}\right)$, and the depth-averaged flow direction, $\theta_{a}$, could be calculated.

$$
\theta_{a}=\frac{1}{H} \int_{0}^{H} \theta(z) d z
$$

Therefore, $\theta_{a(m)}\left(=\sum_{1}^{N} \theta_{a}\right.$, with the number of measurement lines, $N$, equal to 13 in this study), was obtained, which was defined as the lateral mean of $\theta_{a}$ in a section of the meandering compound channel.

Artificial grass was selected to model the floodplain vegetation. The streamwise and lateral intervals between plants were identical $(3 \mathrm{~cm})$, which produced a vegetation density of $m=0.89$ stems $/ \mathrm{cm}^{2}$. Each plant had six blades with a stem width of $d=0.6 \pm 0.1 \mathrm{~cm}$. Thus, the frontal area per unit volume, $a(=m d)$, was used to describe the vegetation density in the field. In this study, $a=0.53$ $\mathrm{cm}^{-1}$, which was chosen as the median of the range of $a$ values $\left(=0.01\right.$ to $\left.1 \mathrm{~cm}^{-1}\right)$ observed in the field (Liu et al. 2016a). The vegetation height $\left(h_{v}\right)$ was 4.0 to $4.5 \mathrm{~cm}$, but vegetation might be deflected depending on the velocity on the floodplains. For example, $h_{v}=2.8 \pm 0.2 \mathrm{~cm}$ in high flows (MV1), but $h_{v}=4.1 \pm 0.2 \mathrm{~cm}$ in low flows (MV3). In the vegetated cases, the zone below the canopy $\left(z<h_{v}\right)$ is associated with higher flow blockage than the zone above the canopy $\left(z>h_{v}\right)$. Therefore, it is reasonable to assign the region below the canopy a distinct non-dimensional density, $a h_{v}$. It is 
anticipated that below the threshold value of $a h_{v}$ (likely to be close to 0.1 based on studies in submerged meadows, Nepf 2012), the root drag would be less than the bed drag, such that the vertical distribution of the mean velocity would not be affected by the floodplain vegetation. However, above the threshold value of $a h_{v}$, the root drag is greater than the bed drag, such that the velocity will diminish within the root zone relative to the boundary layer profile. In this study, $a h_{v}=1.4$ to 2.3 , and the measured velocity profiles are used to determine whether the canopy is considered low or high density. Based on the data from MN1 and MV1 at the apex section (CS1), the vertical profiles of streamwise velocity measured across the floodplain $(y=0.6,1.4,2.2$ and $3.4 \mathrm{~m})$ are shown in Figure 2. In the smooth case (solid black circles), the velocity profile on the floodplain $(y=1.4 \mathrm{~m})$ followed a boundary layer profile. In the vegetated case (red symbols), the velocity below the canopy $\left(z<h_{v}\right)$ was diminished, and the vertical profile no longer followed the boundary layer profile, indicating that the canopy yielded high flow blockage. However, determining the threshold number is not the goal of this study. Instead, the study focuses on how the dense vegetation influences the flow angle along the meandering main channel. The threshold number $\left(a h_{v}=0.1\right)$ reported by Nepf $(2012)$ is used to identify the low- and high-density vegetation. Since $a h_{v}(=1.4$ to 2.3$)$ meets the high-density threshold $(=0.1)$, the vegetation used in this study is representative of dense vegetation, which would produce 
similar flow patterns and depth-averaged flow angles. In addition, at the apex section (CS1), the left floodplain had a width of $0.505 \mathrm{~m}$, which was narrower than the right floodplain whose width was

$2.795 \mathrm{~m}$. However, the influence of the floodplain width on the velocity profile can be considered negligible. Specifically, the vertical profile of streamwise velocity on the left floodplain at $y=0.4 \mathrm{~m}$ (blue crosses in Figure 2) is nearly the same as the velocity profiles on the right floodplain at $y=1.8$, 2.6 and $3.4 \mathrm{~m}$ (red symbols). This implies that the left and right floodplains are sufficiently wide to form a similar flow structure, and the influence of the sidewall on the velocity profiles can be ignored.

The root mean square error (RMSE) is used to estimate the difference between the predictions and measurements and can be expressed as follows:

$$
R M S E=\sqrt{\frac{\sum_{i=1}^{T}\left(X_{p}-X_{m}\right)^{2}}{T}}
$$

where $T$ is the number of measurements and predictions and $X_{p}$ and $X_{m}$ represent the predictions and measurements, respectively. $X_{p}$ and $X_{m}$ can be the height of the secondary current cell $h_{0}$ or the mean depth-averaged flow angle $\theta_{a(m)}$.

\section{Published data}

\subsection{Flume experiments in smooth channels}


The experimental data presented by Shiono and Muto (1998), Muto (1997), and Shiono et al.

(2009) are used to verify the proposed model between the apex section (CS1) and crossover section

(CS4). A brief introduction can be found in Liu et al. (2018a). Additional data from Shige-Eda et al.

(2007) are used to verify the prediction accuracy along a meander. Shige-Eda et al. performed

experiments in a $20.5 \mathrm{~m}$-long and $0.6 \mathrm{~m}$-wide flume. The main channel width and height were $b=0.25$

$\mathrm{m}$ and $h=0.05 \mathrm{~m}$, respectively, yielding $b / h=5$. The sinuosity of the main channel was 1.02 . Two

cases were studied in the smooth channel. One case had a relative flow depth of $\mathrm{Dr}=0.29$ and a valley

slope of $S=2 \%$, and the other case had $D r=0.49$ and $S=0.6 \%$. The inner radius at the apex section

was $r=1.9 \mathrm{~m}$. The geometrical angle between the entrance section and apex section was $\theta_{g e o}=15^{\circ}$.

The measurements were performed at sections with $\theta_{x}=0^{\circ}, 5^{\circ}, 10^{\circ}$ and $15^{\circ}$. The experimental

parameters in the four published studies are summarized in Table 2.

\subsection{Flume experiments and field study of vegetated channels}

The published data from two flume experiments (MartínVide et al., 2008; Shiono et al., 2009) and

one field study (Gunawan et al. 2008) are used to verify the proposed model because, in these studies,

the depth-averaged flow angle was available in at least half a meander, and the information of 
floodplain dense vegetation was reported. Although details of the experiments can be found in

MartínVide et al. (2008), Shiono et al. (2009), and Gunawan et al. (2008), a brief introduction of these

experiments is presented for completeness and convenience. The parameters used in the published

studies are summarized in Table 3.

First, the experiments of MartínVide et al. (2008) were performed in a physical model of a river reach that included a meandering main channel and two floodplains with vegetation. The length and width of the channel were 18.7 and $1.7 \mathrm{~m}$, respectively. The flow in the reach was quasi-uniform. The valley slope $(S)$ was $9.4 \%$. The sinuosity of the meandering main channel $(s)$ was 1.04 , and the slope of the main channel was $9 \%$. The inner radius at the apex section was $r=6.3 \mathrm{~m}$. The geometrical angle between the entrance section and apex section was $\theta_{g e o}=17^{\circ}$. The width $(b)$ and depth $(h)$ of the main channel were 0.4 and $0.038 \mathrm{~m}$, respectively, yielding $b / h=10.5$. One case was introduced herein because the depth-averaged flow directions were available (see Figure 13 in MartínVide et al. (2008)). The discharge of $Q=0.171 \mathrm{~m}^{3} / \mathrm{s}$ produced a flow depth of $H=0.19 \mathrm{~m}$ in the main channel. Gravel with a mean diameter $d_{50}=20 \mathrm{~mm}$ covered the main channel and floodplains, producing a Manning's roughness parameter of $n_{m c}=n_{f p}=0.025$. The floodplain vegetation was simulated using plastic strips with a canopy height of $h_{v}=8 \pm 2 \mathrm{~cm}$. The density of model vegetation on floodplains was $m=0.07$ 
stems $/ \mathrm{cm}^{2}$, and the stem width was $d=2 \pm 1 \mathrm{~mm}$. Thus, $a=0.14 \mathrm{~cm}^{-1}$, yielding $a h_{v}=1.1$, which met the threshold for a high-density canopy $\left(a h_{v}>0.1\right)($ Nepf 2012$)$.

Additional series of experiments were performed in a 13 m-long and 2.4 m-wide flume with a valley slope of $S=2 \%$ at Loughborough University, UK (Shiono et al., 2009). The main channel had a width of $b=0.4 \mathrm{~m}$ and a depth of $h=0.04 \mathrm{~m}$, yielding $b / h=10$. The sinuosity of meandering main channel was $s=1.38$, and the slope of the main channel was $S_{m c}=1.4 \%$. The inner radius at the apex section was $r=0.565 \mathrm{~m}$. The geometrical angle between the entrance section and apex section was $\theta_{\text {geo }}=60^{\circ}$. The depth-averaged two-dimensional flow direction was available in two cases: (1) $\mathrm{Dr}=$ 0.55 with $Q=0.0353 \mathrm{~m}^{3} / \mathrm{s}$ and (2) $D r=0.45$ with $Q=0.0157 \mathrm{~m}^{3} / \mathrm{s}$ (see Figures 7 and 8 in Shiono et al. 2009). Uniform sand with a medium diameter of $0.855 \mathrm{~mm}$ covered the entire main channel, producing a Manning's roughness of $n_{m c} \approx 0.025$. Sufficient sand was placed in the main channel to guarantee that the flume base was not exposed during experiments. In fact, the bedform of the main channel changed slightly due to the secondary current cell, and the mean depth of the main channel $(\approx 4 \mathrm{~cm})$ was the same as the bankfull level. The change in bedform resulted in a negligible influence (within 10\%) on $n_{m c}$. On the floodplain, styrofoam boards were used to produce $n_{f p} \approx 0.015$. Golf grass was affixed on the surface of the styrofoam boards. The grass density was $m=6.5 \mathrm{stems} / \mathrm{cm}^{2}$, the blade width was $d=$ 
$0.4 \mathrm{~mm}$, and $a=0.26 \mathrm{~cm}^{-1}$. The canopy height was $h_{v}=0.7 \pm 0.1 \mathrm{~cm}$. Thus, $a h_{v}=0.2$, which fell in the high-density canopy regime $\left(a h_{v}>0.1\right.$, Nepf 2012).

The field study was conducted on the reach of the River Blackwater, Hampshire, UK (Gunawan et al. 2008). The $300 \mathrm{~m}$-long reach was a double-meandering channel with a valley slope of $S=1 \%$. The sinuosity of the meandering main channel was $s=1.18$. The inner radius $(r \approx 4.7 \mathrm{~m})$ was determined using an inscribed circle at the apex section. The geometrical angle between the entrance section and apex section was $\theta_{g e o}=40^{\circ}$. The width of the main channel was almost the same in the longitudinal direction, with a regular shape that was similar to that of an experimental flume (Sun et al. 2010). The main channel width and depth were $b=4.25 \mathrm{~m}$ and $h=0.75 \mathrm{~m}$, respectively, producing $b / h=5.7$. The Manning's roughness parameter of the main channel was $n_{m c}=0.046$. The hundred-year flood discharge was $4.3 \mathrm{~m}^{3} / \mathrm{s}$, and the bankfull flood discharge in the main channel was $1.5 \mathrm{~m}^{3} / \mathrm{s}$. In January 2008, the velocity profile was measured using an acoustic Doppler current profiler (ADCP) and PIV at the entrance section (CS2) and the apex section (CS5) during a five-hour bankfull flood (the positions of sections are shown in Figure 1 of Gunawan et al. 2008). The discharge was stable, with discharge variation within $10 \%$. In the field study, the measurements were available for the inbank flows at the apex section and entrance section. However, velocity measurements were unavailable because 
overbank flooding was dangerous.

\section{The height of the secondary current cell}

The height of the secondary current cell $\left(h_{0}\right)$ is determined by the height of the cell center. At the entrance section (CS5) of MV1, the vertical profile of the time-averaged lateral velocity, $V$, at the centerline of the cell in the main channel is shown in Figure 3 . The vertical position of $V=0 \mathrm{~cm} / \mathrm{s}$ is considered as the cell center because previous studies reported $V \approx 0 \mathrm{~cm} / \mathrm{s}$ at the center region of the secondary current cell (Shiono and Muto 1998; Knight et al. 2007; Liu et al. 2016a). Thus, the distance from the bottom of the secondary current cell to the center of the cell is denoted as $h_{0(c)}$ (Figure 3 ). Knight et al. (2007) reported that secondary current cells normally exhibit mirror symmetry in the lateral velocities from the bottom of the secondary current cell to the cell center and the lateral

velocities from the cell center to the top of the cell, producing $\int_{0}^{h_{0}} V d z=0$. In Figure 3 , the distance from the bottom of the secondary current cell $(z=0 \mathrm{~cm})$ to the center of the cell $\left(z=h_{O(c)}\right)$ should be the same as the distance from the center of the cell $\left(z=h_{O(c)}\right)$ to the top of the cell $\left(z=h_{0)}\right)$, i.e., $h_{O(c)}=h_{0-}$ $h_{O(c)}$. Thus, $h_{O(c)}=h_{0} / 2$. For example, in Figure $3, h_{O(c)}=8.5 \pm 1.5 \mathrm{~cm}$ is estimated from the distance between the bottom of the cell $(z=0 \mathrm{~cm})$ and the center of the cell, where $V \approx 0 \mathrm{~cm} / \mathrm{s}$ is equal to $h_{0} / 2(=$ 
$8.0 \pm 1.5 \mathrm{~cm}$ ) within uncertainty. In this study, we use $h_{O(c)}$ to determine the height of the secondary

current cell $\left(h_{0}\right)$ through $h_{O(c)}=h_{0} / 2$ and used $\int_{0}^{h_{0}} V d z=0$ to further confirm $h_{0}$. The summary of $h_{0}$ is given in Table 4.

The height of the secondary current cell $\left(h_{0}\right)$ in the middle section (CS2) between the apex section (CS1) and exit section (CS3) is not discussed herein because the secondary current cell is absent in CS2. In most sections, $h_{0}$ in the vegetated channel is greater than that in the smooth channel. In sections CS3, CS4 and CS5 with large section angles $\left(\theta_{x}=60^{\circ}\right), h_{0}$ increased from $h$ (bankfull level) to $h+h_{v}$ (the sum of the bankfull level and vegetation height), as shown in Figure 4a and 4d for CS4. This is because the secondary current cell is suppressed by upstream floodplain flow. In the smooth channel, the flow on floodplains restricts the vertical development of the secondary current cell. However, in the vegetated channel, the additional resistance of floodplain vegetation decreases the velocity below the canopy. For example, for MV1, within the canopy $\left(z<h_{v}\right)$, the streamwise velocity $(U \approx 4 \mathrm{~cm} / \mathrm{s})$ was about $13 \%$ of the mean velocity $(\approx 30 \mathrm{~cm} / \mathrm{s})$ above the canopy $\left(z>h_{v}\right)$. Based on this finding, the floodplain flow above the canopy restricted the vertical development of the cell. In the section between the entrance section (CS5) and apex section (CS7), $k\left(=\frac{\theta_{x}}{\theta_{0}}\right)$ is a dimensionless parameter that reflects the position of the section between CS5 and CS7. For example, the middle section CS6, with $\theta_{x}=30^{\circ}$, 
produces $k=\frac{1}{2}$, and the height of the cell is approximately the same in both smooth and vegetated channels (Figure $4 \mathrm{~b}$ and $4 \mathrm{e}$ ). This result will be discussed in the next paragraph. Overall, the height of the secondary current cell $h_{0}$ can be predicted as follows.

$$
\begin{aligned}
& h_{0}=h+h_{v} \text { between CS3 and CS5 } \\
& h_{0}=(1-k) H+k\left(h+h_{v}\right) \text { between CS5 and CS7 }
\end{aligned}
$$

For CS5, $k=1\left(\theta_{x}=60^{\circ}\right)$, Eq. (3b) can then be simplified to Eq. (3a). Additionally, for CS3, CS4, and CS5 (Eq. (3a)), the height of the cell $h_{0}$ is dependent on the bankfull level $h$ and vegetation height $h_{v}$ but independent of the flow depth $H$. However, in the section between CS5 and CS7 (Eq. (3b)), $h_{0}$ is related to the flow depth $H$, bankfull level $h$, vegetation height $h_{v}$ and section angle $\theta_{x}$. At CS6 with $\theta_{x}=30^{\circ}$, Eq. (3b) can be simplified to $h_{0}=\frac{1}{2}\left[H+\left(h+h_{v}\right)\right]$ because $k=\frac{1}{2}$. Thus, the relation between $H$ and $h+h_{v}$ determines the height of the cell $h_{0}$. For high flows (e.g., $D r=0.45$ ), the flow depth $(H=25.5 \mathrm{~cm})$, which is $52 \%$ greater than $h+h_{v}(=16.8 \pm 0.2 \mathrm{~cm})$, predominantly determines the height of the cell. Based on this finding, the measured heights in smooth and vegetated cases are the same (both are $\left.h_{0}=20.0 \pm 1.5 \mathrm{~cm}\right)$. However, for low flows (e.g., $\left.D r=0.25\right)$, the flow depth $(H=18.8$ $\mathrm{cm})$ is approximately equal to $h+h_{v}(=18.1 \pm 0.2 \mathrm{~cm})$; therefore, the height of the cell in the vegetated case $\left(h_{0}=17.5 \pm 1.5 \mathrm{~cm}\right)$ is greater than that in the smooth case $\left(h_{0}=16.0 \pm 1.5 \mathrm{~cm}\right)$. For 
apex sections CS1 and CS7 $\left(k=\frac{\theta_{x}}{\theta_{g e o}}=0^{\circ}\right)$, the height of the cell $h_{0}$ is only determined by the flow depth $H$, which is the same in the smooth and vegetated channels (Figure 4c and 4f). Finally, the predictions of Eq. (3) exhibit good agreement with the measured heights of the secondary current cell within uncertainty in CS3, CS4, CS5, CS6 and CS7 in both the smooth and vegetated channels (Figure 5; RMSE $=1.9 \mathrm{~cm})$.

\section{Theoretical background}

\subsection{Lateral profile of the depth-averaged flow angle}

Along half a meander (CS1 to CS7), the depth-averaged flow angle $\theta_{a}$ is constant across each section of the meandering main channel, which is supported by the lateral distribution of $\theta_{a}$ in each section (Figure 6). Therefore, the mean depth-averaged flow angle $\theta_{a(m)}$ represents the flow direction in each section of the meandering main channel, which is estimated based on the local flow angle $\theta_{a}$,

i.e., $\theta_{a(m)}=\frac{1}{N} \sum_{1}^{N} \theta_{a}$, where $N$ is the number of $\theta_{a}$ values $\left(N=13\right.$ in this study). The value of $\theta_{a(m)}$ in each section and the standard deviation (SD) are presented in Table 5. The summaries of $\theta_{a(m)}$ and SD further indicate that in each section, the local flow angle is constant in the lateral direction, producing $\theta_{a(m)}=\theta_{a}$ and a small SD. Specifically, the SD among all sections is less than $3^{\circ}$. 


\subsection{Predictive model for a smooth channel}

The secondary current cell is absent in the middle section (CS2) between the apex section (CS1) and exit section (CS3), at which only lateral velocities from right to left are observed (Figure 7a). The vertical profiles of local flow angle at CS2 are shown in Figure 7b. At the interface of the main channel and the upstream floodplain $(y / h=5$, black circles in Figure $7 b)$, water flows downstream in the valley direction and produces a flow angle of $\theta(z)=30.3 \pm 1.8^{\circ}$, which is equal to the section angle $\theta_{x}=30^{\circ}$. In the main channel, the flow angle above the bankfull level $(z>h)$ decreases, and the angle below the bankfull level $(z<h)$ increases as the position moves from the interface of the main channel and floodplain $(y / h=5)$ to the center of the main channel $(y / h=2.5)$. Specifically, at a position close to the upstream floodplain $(y / h=4.6$, blue triangles in Figure $7 b)$, the flow angle is $\theta(z)=23.3^{\circ}$ above

the bankfull level $(z>h)$ and $\theta(z)=5.5^{\circ}$ below the bankfull level $(z<h)$. However, at a position

further from the upstream floodplain $(y / h=3.9$, red squares), the flow angle $\theta(z)$ at $z>h$ decreases to $14.7^{\circ}$, and $\theta(z)$ at $z<h$ increases to $14.3^{\circ}$. This result occurs because the upstream floodplain flow plunges into the main channel at the interface $(y / h=5)$ and expands to occupy the entire main channel, as shown in Figure 7a. Based on the vertical profiles of the local flow angle $\theta(z)$, the integral of the 
flow angle over the flow depth $\left(\int_{0}^{H} \theta(z) d z\right.$ for $y / h=3.9$ and $4.6 ; \int_{h}^{H} \theta(z) d z$ for $\left.y / h=5\right)$ is the same at three positions. Specifically, $\frac{\int_{0}^{H} \theta(z)_{y / h=3.9} d z}{\int_{h}^{H} \theta(z)_{y / h=5} d z}=1.1 \pm 0.1$, and $\frac{\int_{0}^{H} \theta(z)_{y / h=4.6} d z}{\int_{h}^{H} \theta(z)_{y / h=5} d z}=1.0 \pm 0.1$. The same result is confirmed in cases MN2 and MN3 (data not shown). Thus, the following relation is obtained:

$$
\frac{1}{H} \int_{0}^{H} \theta(z) d z=\frac{1}{H} \int_{h}^{H} \theta(z)_{y / h=5} d z
$$

Because $\theta(z)_{y / h=5}=\theta_{x}$ at the interface of the main channel and upstream floodplain $(y / h=5)$,

$\int_{h}^{H} \theta(z)_{y / h=5} d z=(H-h) \theta_{x}$. Therefore, combining Eqs. (1) and (4) yields:

$$
\theta_{a}=\frac{1}{H} \int_{h}^{H} \theta(z)_{y / h=5} d z=\operatorname{Dr} \theta_{x}
$$

As the section proceeded, a secondary current cell is formed between the exit section (CS3) of the previous meander and the entrance section (CS5) of the next meander. Due to the suppression of the upstream floodplain flow, the height of the secondary current cell in CS3, CS4 and CS5 is approximately equal to the bankfull level $(h)$ (Table 4). Note that the depth-averaged flow angle, $\theta_{a}$, is constant across each section in the main channel (see Section 5.1), thus, the prediction of the depth-averaged flow angle at any lateral location across a section is representative of the flow angle in the section. Therefore, $\theta_{a}\left(=\theta_{a(m)}\right)$ is predicted at the centerline of the secondary current cell. Within the secondary current cell $\left(0 \leq z \leq h_{0}\right)$, the local flow angle averaged over the height of the cell $\theta_{\text {cell }}$ is $0^{\circ}$, and above the cell $\left(h_{0} \leq z\right)$, the mean flow angle $\theta_{\text {upper }}$ is equal to the section angle $\theta_{x}$ (e.g., 
the vertical profiles of the local flow angles at CS3 and CS4 in Figure 8). The two relations can be expressed as follows.

$$
\begin{aligned}
& \theta_{\text {cell }}=\frac{1}{h_{0}} \int_{0}^{h_{0}} \theta(z) d z=0^{\circ}(6 \mathrm{a}) \\
& \theta_{\text {upper }}=\frac{1}{H-h_{0}} \int_{h_{0}}^{H} \theta(z) d z=\theta_{x} \quad(6 \mathrm{~b})
\end{aligned}
$$

Eq. (6) is proposed for the exit section (CS3) and crossover section (CS4), which is partially occupied by the secondary current cell, of the meandering main channel. For the meandering compound channel, Liu et al. (2018a) proposed two relations for $\theta_{\text {cell }}$ and $\theta_{\text {upper }}$, which are the same as Eq. (6), between the entrance section (CS5) and apex section (CS7). In that case, the secondary current cell fully occupies the sections. The resulting formulation suggests that the two relations (Eq. (6)) are independent of the width of the secondary current cell and are only dependent with the height of the cell $h_{0}$.

Therefore, Eq. (1) can be rearranged as follows.

$$
\theta_{a}=\frac{h_{0}}{H}\left[\frac{1}{h_{0}} \int_{0}^{h_{0}} \theta(z) d z\right]+\frac{H-h_{0}}{H}\left[\frac{1}{H-h_{0}} \int_{h_{0}}^{H} \theta(z) d z\right]=\frac{H-h_{0}}{H} \theta_{x}
$$

Between the exit section (CS3) and the entrance section (CS5), the height of the secondary current cell is equal to the bankfull height, i.e., $h_{0} \approx h$ (see cases MN1 to MN3 in Table 4), thereby producing $\frac{H-h_{0}}{H} \approx \frac{H-h}{H}=D r$. Thus, Eq. (7) can be rewritten as follows. 
$\theta_{a}=\operatorname{Dr} \theta_{x}(8)$

Notably, Eq. (8) is the same as Eq. (5). The advantage is that Eqs. (5) and (8) can be used to

predict the depth-averaged flow angle $\theta_{a}$ between the middle sections (CS2) of the apex and exit

sections and the entrance section (CS5) regardless of the presence or absence of secondary current

cells.

Finally, Liu et al. (2018a) proposed a predictive equation for the depth-averaged flow angle only

between the entrance section (CS5) and the apex section (CS7). Liu et al. reported that the height of the

cell increased with the section position and proposed a relation for estimating the height of the cell,

$h_{0}=H-k(H-h)$. Thus, Eq. (7) could be rewritten as follows.

$\theta_{a}=k \operatorname{Dr} \theta_{x}(9)$

At the apex sections (CS1 and CS7), $\theta_{a}=0^{\circ}$ (see Figure 6) because of $\theta_{x}=0^{\circ}$. It is noted that

the relation $\left(h_{0}=H-k(H-h)\right)$ is valid in the meander bend region, which is constructed based on

section of a circle. For example, the relation is valid in a channel with a one-third circular geometry in

a meander bend (see discussion in Liu et al. 2018a). However, the relation is only verified using one

section between the entrance and apex sections and this limitation will be discussed later. It is noted

that the relation might change in a meander with other curves, e.g., a sinusoidal curve, because in that 
case, $k\left(=\frac{\theta_{x}}{\theta_{0}}\right)$ incorrectly indicates the section position. However, Eq. (7) can be still used to predict the depth-averaged flow angle if an accurate $h_{0}$ is provided.

\subsection{Predictive model for a vegetated channel}

Similar to the smooth case, at CS2, the secondary current cell is not observed in the vegetated case,

and instead, the lateral velocity from the right to left influences the entire main channel (see Figure 12

in Liu et al. 2016). The influence of floodplain vegetation on the local flow angle $\theta(z)$ is negligible,

as further supported by the vertical profiles of $\theta(z)$ in Figure 9, based on the data from cases MN1

(blue circles) and MV1 (red squares). The vertical profiles in smooth and vegetated channels are

approximately overlapping. Furthermore, based on Eq. (5), the depth-averaged flow angle at CS2 is

only related to the relative flow depth $(D r)$ because the section angle is constant at $\theta_{x}=30^{\circ}$. This

finding is supported by our observations, which shows that for the same $D r, \theta_{a(m)}$ is the same in the

smooth and vegetated channels (the third column, Table 5). Therefore, in the vegetated meandering

compound channel, Eq. (5) $\left(\theta_{a}=\theta_{a(m)}=\operatorname{Dr} \theta_{x}\right)$ can also be used to predict the depth-averaged flow

angle at CS2.

For section CS3, CS4 and CS5, the height of the secondary current cell in the vegetated case is 
$h_{0}=h+h_{v}$ due to the influence of floodplain vegetation (see Section 4). According to Eq. (6), the mean flow angle within the cell $\theta_{\text {cell }}$ and the mean flow angle above the cell $\theta_{\text {upper }}$ are estimated based on the new height of the secondary current cell $h_{0}\left(=h+h_{v}\right)$. For example, at CS5 with $\theta_{x}=60^{\circ}, h_{0}=16.0 \pm 1.5 \mathrm{~cm}$ in the vegetated case (MV1) is greater than $h_{0}=13.0 \pm 1.5 \mathrm{~cm}$ in the smooth case (MN1). When the influence of the dense floodplain vegetation is not considered (i.e., using $h_{0}=13.0 \pm 1.5$ for the calculation $), \theta_{\text {cell }}=-5.9^{\circ}\left(<0^{\circ}\right)$ and $\theta_{\text {upper }}=51.7^{\circ}(16 \%$ smaller than $\left.\theta_{x}=60^{\circ}\right)$ can be obtained, but these values do not satisfy Eq. (6). However, $\theta_{\text {cell }}=0.6^{\circ}\left(\approx 0^{\circ}\right)$ and $\theta_{\text {upper }}=59.2^{\circ}\left(\approx \theta_{x}\right)$ are obtained for $h_{0}=16.0 \pm 1.5$, and these results are consistent with Eq. (6).

For middle section CS6 and apex section (CS7 or CS1), the height of the cell is estimated using Eq. (3b), i.e., $h_{0}=(1-k) H+k\left(h+h_{v}\right)$. Based on the date from MV1 to MV3, at CS6, $\theta_{\text {cell }}(=$ $\left.0^{\circ}\right)$ estimated over $h_{0}$ and $\theta_{\text {upper }}\left(=32.9^{\circ}\right) \approx \theta_{x}\left(=30^{\circ}\right)$ estimated over $H-h_{0}$ satisfies Eq. (6). Based on these findings, Eqs. (7) and (3) are combined and rewritten as follows.

$\theta_{a}=\frac{H-\left(h+h_{v}\right)}{H} \theta_{x}$ between CS3 and CS5

$\theta_{a}=\frac{k\left[H-\left(h+h_{v}\right)\right]}{H} \theta_{x}$ between CS5 and CS7

Overall, in an entire meander, the mean depth-averaged flow angle $\theta_{a(m)}\left(=\theta_{a}\right)$ in the 
meandering main channel can be estimated at CS2, where the secondary current cell is absent, using Eq.

(5); at CS3, CS4 and CS5, where $h_{0}=h+h_{v}$, using Eq. (10a); and at CS6 and CS7 (also CS1), where $h_{0}>h+h_{v}$, using Eq. (10b).

\section{Results}

\subsection{Model verification for the smooth channel}

For the smooth channel, this study focuses on the comparison between the predicted mean

depth-averaged flow angle $\theta_{a(m)}$ and the measured value between only the apex section (CS1) and crossover section (CS4) (Figure 10). The predictive equation (Eq. (9)) between the entrance section (CS5) and apex section (CS7) is verified by Liu et al. (2018a). For the apex section (e.g., CS1) and crossover section (e.g., CS4), the data from Shiono and Muto (1998), Muto (1997), Shiono et al. (2009) and our experiments are used to verify Eqs. (5) and (7). The data from Shige-Eda et al. (2007) along an entire meander are used to further verify the model. In all cases, the RMSEs of the mean depth-averaged flow angle $\theta_{a(m)}$ are summarized in Table 6.

First, the predictions and measurements are compared between CS1 and CS4 based on the data from Shiono and Muto (1998), Muto (1997), Shiono et al. (2009) and our experiments. Figure 10 
shows that good agreement is obtained between the predicted and measured depth-averaged flow angles. Specifically, the RMSE mainly ranges between $2.4^{\circ}$ to $3.8^{\circ}$ though reaches $6.5^{\circ}$ for the data of Shiono et al. (2009). This relatively large RMSE for the data of Shiono et al. (2009) is perhaps ascribed to the fact that in Shiono et al. (2009) experiment, a mobile bed was used, which slightly changed during experiments due to possible scour and deposit, resulting in changes in the local flow depth and flow angle. Second, using the proposed model (Eqs. (4) and (6)) of CS1 and CS4 and the previous model of Liu et al. (2018a), the flow angle along a meander is predicted. The flow angles measured by Shige-Eda et al. (2007) along an entire meander agree well with the predicted values (orange diamonds in Figure 10), with an RMSE $=1.9^{\circ}$. Overall, in smooth meandering compound channels over a wide range of sinuosity values $(s=1.02$ to 1.57$)$, relative flow depths $(\mathrm{Dr}=0$ to 0.5$)$ and main channel width to height ratios $(b / h=2.8$ to 10$)$ (see Table 2$)$, the measured depth-averaged flow angles $\theta_{a(m)}$ agree well with the predicted $\theta_{a(m)}$ values between CS1 and CS4. This indicates that the depth-averaged flow angle can be accurately estimated along an entire meander using the proposed model, namely Eqs. (5) and (7) and the equations in Liu et al. (2018a).

\subsection{Model verification for the vegetated channel}


The measurements from flume experiments (MartínVide et al. 2008, Shiono et al. 2009 and this study) and a field study (Gunawan et al. 2008) are used to verify the proposed model (Eqs. (5) and (10)) along half a meander (CS1 to CS7) in the meandering compound channel with dense vegetation on floodplains. First, our experiments are performed in a channel with a non-mobile bed. The predicted flow angle is close to the measured angle, with an RMSE of $3.2^{\circ}$ (Red circles in Figure 11). Second, the model is verified in a channel with the bed covered by gravel with a diameter of $d_{50}=20 \mathrm{~mm}$ (MartínVide et al. (2008). The bed was not changed at the highest flow condition $(D r=0.8)$. This bed condition is a typical scenario in natural rivers, in which an armor layer often forms. The predicted flow angle is consistent with the measured value, and the RMSE between the measurement and prediction is $1.6^{\circ}$ (black circles in Figure 11). Third, the model is verified using the data recorded in a mobile bed channel (Shiono et al. (2009)). The predicted mean flow angle agrees with the measured value, producing an RMSE of $4.3^{\circ}$ (blue triangles in Figure 11). The high uncertainty of the measured mean flow angle is attributed to ripples formed on the bed, which resulted in a change in the local flow depth and thus variations in the local flow angle. Although our model does not consider the local change in the flow depth, the model is still able to accurately predict the mean depth-averaged flow angle along a meander. Finally, the measured flow angle from a field study (Gunawan et al. (2008)) 
shows good agreement with the predicted value with an RMSE of $2.6^{\circ}$. These good comparisons

between prediction and flume measurements and field observations demonstrate that the proposed

model is capable of accurately predicting the depth-averaged flow angle in the vegetated meandering

compound channel.

\section{Discussion}

In the vegetated channel, the height of the dense floodplain vegetation $h_{v}$ influences the

predicted $\theta_{a}$ because the height of the vegetation controls the height of the cell as shown in Eq. (3).

Along a meander, $\theta_{x}$ and $k$ are fixed for a section, so the predicted $\theta_{a}$ in Eq. (10) is affected by $h_{v}$.

In Eq. (10), $\frac{H-\left(h+h_{v}\right)}{H}$ can be rewritten as $1-\frac{h}{H}-\frac{h_{v}}{H}$. When $\frac{h}{H}$ and $\frac{h_{v}}{H}$ are comparable, both

dominate the prediction. A smaller prediction of $\theta_{a}$ is expected when the influence of dense floodplain

vegetation is included $\left(\frac{h_{v}}{H}\right.$ is included) comparing with the prediction in smooth channel where $\frac{h_{v}}{H}=0$.

For example, based on our experiments (MN1 to MN3 and MV1 to MV3) in the crossover section

(CS4), $\frac{h_{v}}{H}(=0.1$ to 0.22$)$ is 18 to $30 \%$ of $\frac{h}{H}(=0.55$ to 0.74$)$, yielding 16 to $96 \%$ smaller prediction in the vegetated channel compared to that in the smooth channel. Similarly, $\frac{h_{v}}{H}$ is $211 \%$ and $18 \%$ of $\frac{h}{H}$ in the cases of MartínVide et al. (2008) and Shiono et al. (2009), respectively, and 74\% and 26\% average 
overestimations of $\theta_{a}$ are obtained, respectively, when the influence of dense vegetation is ignored (i.e., $\frac{h_{v}}{H}=0$ ). Overall, accurate predictions can be achieved only if the influence of dense vegetation on floodplains is included. However, when $\frac{h_{v}}{H}$ is negligible compared to $\frac{h}{H}$ (e.g., $\frac{h_{v}}{H} \approx 0.01 \frac{h}{H}$ ), the influence of floodplain vegetation on the prediction can be ignored, even though the vegetation is dense.

In both smooth and vegetated channels, although the section angle $\theta_{x}\left(=30^{\circ}\right)$ is the same for the two middle sections (CS2 and CS6), the depth-averaged flow angle at CS6 is smaller than that at CS2 (see Table 5). Specifically, the value of $\theta_{a(m)}$ at CS6 is $44 \%$ of the $\theta_{a(m)}$ value at CS2. This result occurs because the presence of a secondary current cell at CS6 produces negative local flow angles, resulting in a smaller depth-averaged flow angle compared to that at CS2, where the secondary current cell is absent. For example, based on the data from MN1 (smooth channel) and MV1 (vegetated channel), the vertical profiles of the local flow angle $\theta(z)$ close to the interface of the main channel and upstream floodplain $(y / h=4.6)$ in both channels are compared in Figure 12. At CS2 (black circles), $\theta(z)$ is larger than $0^{\circ}$ over the flow depth because no secondary current cell is observed (Figure 7a). In contrast, at CS6, where the secondary current cell occurs (Figure 12 in Liu et al. 2016a), $\theta(z)<0^{\circ}$ takes place below the bankfull level $(z<h)$. Since local flow angles above the bankfull level are nearly 
the same $\left(\theta(z) \approx 25^{\circ}\right.$ to $\left.30^{\circ}\right)$ at CS2 and CS6, the offset of positive $\theta(z)(z>h)$ and negative $\theta(z)$ $(z<h)$ produce a smaller depth-averaged flow angle $\left(\theta_{a}=8.7^{\circ}\right)$ compared to the depth-averaged flow angle $\left(\theta_{a}=13.5^{\circ}\right)$ at $\mathrm{CS} 2$.

In the smooth and vegetated channels, Figure 4 indicates that when the relative flow depth $D r=$ 0.45 , the secondary current cell rotates in a counter-clockwise direction (looking downstream). The same rotation direction for the secondary current cell at $D r=0.5$ is reported by Shiono and Muto (1998). In this study, we did not perform measurements of inbank flows, so the experimental observations of Shiono and Muto (1998) are used to discuss the rotation direction of the secondary current cell for inbank flow $(D r=0)$ and overbank flow $(D r=0.5)$. Shiono and Muto confirmed that for $D r=0$, the secondary current cell rotated in the clockwise direction at bend apexes, and this pattern completely differed from the counter-clockwise rotating cell at $D r=0.5$. However, the rotational direction does not affect the mean depth-averaged flow angle $\theta_{a(m)}$. Based on the experimental data of Shiono and Muto (1998), at apex sections, $\theta_{a(m)}=-1.2 \pm 1.1$ for inbank flows $(D r=0)$, which is equal to $\theta_{a(m)}=-0.2 \pm 1.1$ for overbank flows $(D r=0.5)$. Therefore, the proposed model is independent of the rotational direction of the secondary current cell, and the measured $\theta_{a(m)}$ is equal to the predicted $\theta_{a(m)}\left(=0^{\circ}\right)$ regardless of the rotation direction of the secondary current cell. 
No detailed experimental measurements between the entrance section (CS5) and apex section (CS7) are available to further verify Eq. (3b). However, we reiterate that the model of the mean depth-averaged flow angle $\theta_{a(m)}$ is proposed based on the prediction of the height of the secondary current cell $h_{0}$. In other words, the accuracy of the predicted $\theta_{a(m)}$ is highly related to $h_{0}$. The data of Shige-Eda et al. (2007) are used for comparison because they performed measurements at two sections $\left(\theta_{x}=5^{\circ}\right.$ and $\left.10^{\circ}\right)$ between the entrance and apex sections with a geometrical angle of $\theta_{g e o}=15^{\circ}$. In the two sections, the predicted $\theta_{a(m)}$ values highly agree with the measured $\theta_{a(m)}$ values, with an RMSE of only $1.9^{\circ}$. This result indicates that the proposed model can accurately predict not only the depth-averaged flow angle but also the height of the secondary current cell. Finally, the model limitations are discussed. First, this model is proposed under quasi-uniform flow conditions in a meandering channel with overbank flows, and flow is fully developed. Further validation is needed if applied for other flow conditions. Second, a dense canopy with $a h_{v}=0.53$ is used in this study to represent the influence of dense vegetation. However, when low-density vegetation $\left(a h_{v}<0.1\right)$ occurs on floodplains, the velocity profile on floodplains is expected to be similar to the boundary layer profile and produces a negligible influence on the height of the secondary current cell and the depth-averaged flow angle. Thus, the model for the smooth channel can be used to 
perform the prediction. Third, this model is verified in a meandering compound channel with dense vegetation, where $b / h=5$ to 10.5 and $s=1.04$ to 1.38 at $D r=0$ to 0.55 (including inbank and overbank cases). Forth, in our experiments and previous studies, dense vegetation covers entire floodplains. However, in natural rivers, vegetation may partially occupy floodplains, yielding a non-uniform resistance across the floodplain. Wormleaton et al. (2004) increased floodplain roughness using expanded metal strips with an interval of $50 \mathrm{~cm}$ in the longitudinal direction (see Figure 3 in Wormleaton et al. 2004). The $10 \mathrm{~cm}$-high submerged strips produced vertical vortices directly behind them, and these vortices were similar to the vertical vortices visualized by fluorescein behind submerged vegetation patches (Liu et al. 2018b). Therefore, some water was trapped in the space between strips, and the influence of non-uniformly distributed strips on the secondary current cell of the meandering main channel differs from the influence of uniformly distributed dense vegetation on the secondary current cell. Finally, based on previous observations (Liu et al. 2016a; Shiono and Muto 1998), the secondary current cell was absent between CS1 and CS2, and a new cell formed between CS2 and CS3. Therefore, secondary current cells are absent in CS2 and in the sections near CS2, which is where Eq. (5) is capable of predicting the depth-averaged flow angle. This is because Eq. (5) is derived for those sections (e.g., CS2) without a secondary current cell. For the other sections between 
CS1 and CS3 (except CS2 and its surrounding sections), secondary current cells are present but the height of the cell $\left(h_{0}\right)$ could change due to the influence from upstream floodplain flows. Regardless, Eq. (7) can be used to predict the depth-averaged flow angle if the height of the secondary current cell $\left(h_{0}\right)$ is provided accurately.

\section{Summary}

This study proposes a model for predicting the depth-averaged flow angle along a meander in smooth and vegetated meandering compound channels. A series of laboratory experiments is performed in a large-scale meandering channel with smooth and vegetated floodplains. In the meandering main channel, the height of the secondary current cell in the vegetated case is increased by the presence of dense floodplain vegetation compared to that condition in the smooth case. A predictive method of determining the height of the cell is presented. For the middle section between the apex and exit sections, in which a secondary current cell is not observed, the depth-averaged flow angle is independent of the secondary current cell and is related to the relative flow depth and section angle (Eq.

(5)). In other sections where the secondary current cell is formed, the depth-averaged flow angle is dependent on the height of the secondary current cell. The local flow angle averaged over the height of 
the cell and the mean flow angle above the cell are verified to be $0^{\circ}$ and the section angle, respectively, in smooth and vegetated channels (Eq. (6)). Finally, the model is validated using the data from published studies and the authors' measurements. The predictions agree well with measurements, indicating that the proposed model can accurately predict the depth-averaged flow angle along a meander in smooth and vegetated meandering compound channels.

\section{Acknowledgments}

This study was financially supported by the National Key Research and Development Program of China (No. 2016YFC0402302), and the National Natural Science Foundation of China (Nos. 51709022, 51609160 and 51539007). Yuqi Shan would like to acknowledge the support from the Open Fund from the State Key Laboratory of Hydraulics and Mountain River Engineering, Sichuan University (SKHL1623) and the Scientific Research Foundation of Chengdu University of Information Technology (KYTZ201710). Chao Liu would like to acknowledge the support from the Fundamental Research Funds for the Central Universities (YJ201633) and the Huo Hua Ku Programme of Sichuan University (2018SCUH0020). Chao Liu, Yakun Guo and Kejun Yang were supported by the Programme of Introducing Talents of Discipline to Universities (BC2018038). The authors would like to thank the anonymous reviewers for their valuable comments and suggestions that significantly improved the quality of the paper. 


\section{Notation}

\begin{tabular}{|c|c|c|}
\hline$A$ & $=$ & cross-sectional area at an apex section \\
\hline$a$ & $=$ & frontal area per unit volume $(=m d)$ \\
\hline$B$ & $=$ & channel width \\
\hline$b$ & $=$ & width of meandering main channel \\
\hline $\mathrm{Dr}$ & $=$ & relative flow depth $\left(=\frac{H-h}{H}\right)$ \\
\hline$d$ & $=$ & stem width \\
\hline$H$ & $=$ & flow depth in the meandering main channel \\
\hline$h$ & $=$ & bankfull level \\
\hline$h_{0}$ & $=$ & height of the secondary current cell \\
\hline$h_{0(c)}$ & $=$ & $\begin{array}{l}\text { distance from the bottom of secondary current cell to the center of the cell (= } \\
\left.h_{0} / 2\right)\end{array}$ \\
\hline$h_{v}$ & $=$ & vegetation height \\
\hline$k$ & $=$ & dimensionless parameter $\left(=\frac{\theta_{x}}{\theta_{\text {geo }}}\right)$ \\
\hline$L_{w}$ & $=$ & wavelength in a half meander (see Figure 1) \\
\hline$L_{v}$ & $=$ & valley length in a half meander (see Figure 1) \\
\hline$m$ & $=$ & vegetation density \\
\hline$N$ & $=$ & the number of measurement lines (i.e., $N=13$ in our study) \\
\hline$n$ & $=$ & Manning's roughness parameter \\
\hline$Q$ & $=$ & channel discharge \\
\hline$R$ & $=$ & hydraulic radius at the apex section \\
\hline $\operatorname{Re}$ & $=$ & Reynolds number $\left(=\frac{Q R}{A v}\right)$ \\
\hline$r$ & $=$ & inner radius of a meander bend \\
\hline$S$ & $=$ & valley slope \\
\hline$S_{m c}$ & $=$ & slope of the meandering main channel \\
\hline$s$ & $=$ & sinuosity of the meandering main channel $\left(=L_{w} / L_{v}\right)$ \\
\hline$T$ & & number of the measurement and prediction \\
\hline$U, V, W$ & $=$ & $\begin{array}{l}\text { time-averaged velocities in the streamwise, lateral and vertical directions, } \\
\text { respectively }\end{array}$ \\
\hline
\end{tabular}




\begin{tabular}{|c|c|l|}
\hline$x, y, z$ & $=$ & streamwise, lateral and vertical directions, respectively (Figure 1) \\
\hline$X_{p}$ & $=$ & a prediction \\
\hline$X_{m}$ & & a measurement \\
\hline$\theta_{a}$ & $=$ & depth-averaged two-dimensional flow direction (Eq. (1)) \\
\hline$\theta_{a(m)}$ & $=$ & lateral mean of $\theta_{a}$ \\
\hline$\theta_{\text {cell }}$ & $=$ & mean of the local flow direction within the secondary current cell (Eq. (6a)) \\
\hline$\theta_{\text {upper }}$ & $=$ & mean of the local flow direction above the cell secondary current cell (Eq. (6b)); \\
\hline$\theta_{\text {geo }}$ & $=$ & $\begin{array}{l}\text { geometrical angle of the region between the entrance and apex sections (see } \\
\text { Figure 1) }\end{array}$ \\
\hline$\theta_{x}$ & $=$ & section angle (see Figure 1) \\
\hline$\theta_{(z)}$ & $=$ & local flow direction (= $\arctan \frac{\mathrm{V}}{U}$ ) \\
\hline$v$ & $=$ & kinematic viscosity \\
\hline
\end{tabular}

\section{References}

Chen, R., Shao, S., Liu, X., Zhou, X., 2015. Applications of Shallow Water SPH Model in Mountainous Rivers. Journal of Applied Fluid Mechanics, 8(4): 863-870.

http://dx.doi.org/10.18869/acadpub.jafm.73.238.23311

Ding, Y., Liu, Y., Liu, X., Chen, R., Shao, S. 2017. Applications of Coupled Explicit-Implicit Solution of SWEs for Unsteady Flow in Yangtze River. Water, 9, 91.

http://dx.doi.org/10.3390/w9030091 
Goring, D. G., Nikora, V. I., 2002. Despiking acoustic doppler velocimeter data. Journal of Hydraulic Engineering 128, 117-126. http://dx.doi.org/10.1061/(ASCE)0733-9429(2002)128:1(117)

Gunawan, B., Sun, X., Sterling, M., Knight, D.W., Shiono, K., Chandler, J.H., Rameshwaran, P., Wright, N.G., Sellin, R.H.J., Tang, X., Fujita, I., 2008. An integrated and novel approach to estimating the conveyance capacity of the River Blackwater, Proceedings of the Eight International Conference on Hydro-Science and Engineering, Nagoya, Japan, pp. 8-12.

Harrison, L.R., Dunne, T., Fisher, G.B., 2015. Hydraulic and geomorphic processes in an overbank flood along a meandering, gravel-bed river: implications for chute formation. Earth Surface Processes \& Landforms, 40(9): 1239-1253. http://dx.doi.org/10.1002/esp.3717

Ismail, Z., 2007. A study of overbank flows in non-vegetated and vegetated floodplains in compound meandering channels. University of Loughborough.

Jing, H., Guo, Y., Li, C., Zhang, J., 2009. Three-dimensional numerical simulation of compound meandering open channel flow by the Reynolds stress model. International Journal for Numerical Methods in Fluids, 59, 927-943. http://dx.doi.org/10.1002/fld.1855 
Keevil, G. M., Peakall, J., Best, J. L., \& Amos, K. J. (2006). Flow structure in sinuous submarine channels: velocity and turbulence structure of an experimental submarine channel. Marine Geology, 229(3), 241-257. http://dx.doi.org/10.1016/j.margeo.2006.03.010

Knight, D.W., Omran, M., Tang, X., 2007. Modeling depth-averaged velocity and boundary shear in trapezoidal channels with secondary flows. Journal of Hydraulic Engineering 133, 39-47. http://dx.doi.org/10.1061/(ASCE)0733-9429(2007)133:1(39)

Liu, C., Luo, X., Liu, X., Yang, K., 2013. Modeling depth-averaged velocity and bed shear stress in compound channels with emergent and submerged vegetation. Advances in Water Resources 60, 148-159. http://dx.doi.org/10.1016/j.advwatres.2013.08.002

Liu, C., Wright, N., Liu, X., Yang, K., 2014. An analytical model for lateral depth-averaged velocity distributions along a meander in curved compound channels. Advances in Water Resources 74, 26-43. http://dx.doi.org/10.1016/j.advwatres.2014.08.003

Liu, C., Nepf, H., 2016. Sediment deposition within and around a finite patch of model vegetation over a range of channel velocity. Water Resources Research 52(1), 600-612. http://dx.doi.org/10.1002/2015WR018249 
Liu, C., Shan, Y., Liu, X., Yang, K., Liao, H., 2016a. The effect of floodplain grass on the flow characteristics of meandering compound channels. Journal of Hydrology 542, 1-17. http://dx.doi.org/10.1016/j.jhydrol.2016.07.037

Liu, C., Shan, Y., Liu, X., Yang, K., 2016b. Method for assessing discharge in meandering compound channels. Proceedings of the Institution of Civil Engineers-Water Management 169, 17-29. http://dx.doi.org/10.1680/wama.14.00131

Liu, X., Zhou, Q., Huang, S., Guo, Y., Liu C, 2018a. Estimation of flow direction in meandering compound channels. Journal of Hydrology, 556, 143-153. https://doi.org/10.1016/j.jhydrol.2017.10.071

Liu, C., Hu, Z., Lei, J., Nepf H., 2018b. Vortex structure and sediment deposition in the wake behind a finite patch of model submerged vegetation. Journal of Hydraulic Engineering, 144(2), 04017065. http://dx.doi.org/10.1061/(ASCE)HY.1943-7900.0001408

Lyness, J.F., Myers, W.R.C., Cassells, J.B.C., O’Sullivan, J.J., 2001. The influence of planform on flow resistance in mobile bed compound channels. Proceedings of the ICE-Water and Maritime Engineering, 148(1): 5-14. https://doi.org/10.1680/wame.2001.148.1.5 
MartínVide J.P., Moreta P.J.M., LópezQuerol. S., 2008. Improved 1-D modelling in compound

meandering channels with vegetated floodplains. Journal of Hydraulic Research, 46, 265-276.

http://dx.doi.org/10.1080/00221686.2008.9521860

Nepf, H.M., 2012. Flow and transport in regions with aquatic vegetation. Annual Review of Fluid Mechanics 44, 123-142. http://dx.doi.org/10.1146/annurev-fluid-120710-101048

Nikora, N., Nikora, V., O’Donoghue, T., 2013. Velocity profiles in vegetated open-channel flows: combined effects of multiple mechanisms. Journal of Hydraulic Engineering 139, 1021-1032. http://dx.doi.org/10.1061/(ASCE)HY.1943-7900.0000779

Shan, Y., Liu, C., Luo, M., 2015. Simple analytical model for depth-averaged velocity in meandering compound channels. Applied Mathematics and Mechanics 36, 707-718.

http://dx.doi.org/10.1007/s10483-015-1943-6

Shan, Y., Liu, X., Yang, K., Liu, C., 2017. Analytical model for stage-discharge estimation in meandering compound channels with submerged flexible vegetation. Advances in Water Resources, 2017, 108, 170-183. http://dx.doi.org/10.1016/j.advwatres.2017.07.021

Shige-eda M, Asai K., Sakamoto H., Nishio T., Akiyama J., Ishihara J., Higuchi N., Tokunaga T, 2007. Effects of vegetation along a low-water channel on behavior of flood flows in a meandering 
compound channel. Proceedings of Hydraulic engineering, 51: 643-648 (in Japanese).

https://doi.org/10.2208/prohe.51.643

Shiono, K., Chan, T.L., Spooner, J., Rameshwaran, P., Chandler, J.H., 2009. The effect of floodplain roughness on flow structures, bedforms and sediment transport rates in meandering channels with overbank flows: part I. Journal of Hydraulic Research 47, 5-19.

http://dx.doi.org/10.3826/jhr.2009.2944-I

Shiono, K., Muto, Y., 1998. Complex flow mechanisms in compound meandering channels with overbank flow. Journal of Fluid Mechanics 376, 221-261.

https://doi.org/10.1017/S0022112098002869

Sun, X., Shiono, K., Rameshwaran, P., Chandler, J.H., 2010. Modelling vegetation effects in irregular meandering river. Journal of Hydraulic Research 48, 775-783.

http://dx.doi.org/10.1080/00221686.2010.531101

Wang, B., Jia, D., Zhou, G., \& Shao, X. (2009). An experimental investigation on flow structure in channel with consecutive bends. Advances in Water Resources and Hydraulic Engineering, 1811-1816. https://doi.org/10.1007/978-3-540-89465-0_312 
Wormleaton, P.R., Sellin, R.H.J., Bryant, T., 2004. Flow structures in a two-stage channel with a

mobile bed. Journal of Hydraulic Research, 42(2): 145-162.

http://dx.doi.org/10.1080/00221686.2004.9628300

Wu, W., Shields, F. D., Bennett, S. J., \& Wang, S. S. (2005). A depth-averaged two-dimensional model for flow, sediment transport, and bed topography in curved channels with riparian vegetation. Water Resources Research, 41(3), W03015.

https://doi.org/10.1029/2004WR003730

Yang, K., Cao, S., Knight, D.W., 2007. Flow patterns in compound channels with vegetated floodplains. Journal of Hydraulic Engineering 133, 148-159.

http://dx.doi.org/10.1061/(ASCE)0733-9429(2007)133:2(148) 
Table 1 Summary of experimental parameters used in this study ${ }^{\text {a }}$

\begin{tabular}{|c|c|c|c|c|c|}
\hline Case & $Q\left(\mathrm{~m}^{3} / \mathrm{s}\right)$ & $R e$ & $H(\mathrm{~cm})$ & $h_{v}(\mathrm{~cm})$ & $D r$ \\
\hline MV1 & 0.149 & 33,023 & 25.6 & $2.8 \pm 0.2$ & 0.45 \\
\hline MV2 & 0.093 & 21,065 & 21.7 & $3.5 \pm 0.2$ & 0.35 \\
\hline MV3 & 0.067 & 15,311 & 18.8 & $4.1 \pm 0.2$ & 0.26 \\
\hline MN1 & 0.189 & 41,987 & 25.5 & - & 0.45 \\
\hline MN2 & 0.113 & 25,582 & 21.6 & - & 0.35 \\
\hline MN3 & 0.085 & 19,415 & 18.9 & - & 0.26 \\
\hline
\end{tabular}

${ }^{a} Q$ is the channel discharge; $\operatorname{Re}\left(=\frac{Q R}{A v}\right)$ is the Reynolds number at the apex section, in which $A$ is the area of the transect at the apex section, $R$ is the hydraulic radius and $v\left(=0.01 \mathrm{~cm}^{2} / \mathrm{s}\right)$ is the kinematic viscosity; $H$ is the main channel flow depth; $\operatorname{Dr}\left(=\frac{H-h}{H}\right)$ is the relative flow depth; $h$ is the bankfull level; and $h_{v}$ is the vegetation height.

Table 2 Experimental parameters for smooth channels ${ }^{\mathrm{a}}$

\begin{tabular}{|c|c|c|c|c|c|c|c|c|c|c|}
\hline Source & $\begin{array}{c}S \\
(\%)\end{array}$ & $\begin{array}{c}S_{m c} \\
(\%)\end{array}$ & $s$ & $\begin{array}{c}r \\
(\mathrm{~cm})\end{array}$ & $\begin{array}{c}b \\
(\mathrm{~cm})\end{array}$ & $\begin{array}{c}h \\
(\mathrm{~cm})\end{array}$ & $b / h$ & $\begin{array}{c}H \\
(\mathrm{~cm})\end{array}$ & $D r$ & $\theta_{\text {geo }}\left({ }^{\circ}\right)$ \\
\hline \multirow{3}{*}{$\begin{array}{c}\text { Shiono and Muto } \\
(1998)\end{array}$} & 1 & 0.73 & 1.37 & 35 & 15 & 5.3 & 2.8 & 10.6 & 0.5 & 60 \\
\cline { 2 - 12 } & 1 & 0.73 & 1.37 & 35 & 15 & 5.3 & 2.8 & 6.2 & 0.15 & 60 \\
\cline { 2 - 12 } & 1 & 0.73 & 1.37 & 35 & 15 & 5.3 & 2.8 & 5.3 & 0 & 60 \\
\hline \multirow{3}{*}{\begin{tabular}{c} 
Muto (1997) \\
\cline { 2 - 12 }
\end{tabular}} & 1 & 0.64 & 1.57 & 35 & 15 & 5.3 & 2.8 & 10.6 & 0.5 & 60 \\
\hline \multirow{2}{*}{$\begin{array}{c}\text { Shige-Eda et al. } \\
(2007)\end{array}$} & 2 & 1.96 & 1.02 & 190 & 25 & 5 & 5 & 7.0 & 0.29 & 15 \\
\hline & 0.6 & 0.59 & 1.02 & 190 & 25 & 5 & 5 & 9.8 & 0.49 & 15 \\
\hline $\begin{array}{c}\text { Shiono et al. } \\
(2009)\end{array}$ & 2 & 1.45 & 1.38 & 56.5 & 40 & 4 & 10 & 5.7 & 0.3 & 60 \\
\hline
\end{tabular}

${ }^{a} S$ is the valley slope; $S_{m c}$ is the slope of meandering main channel; $s$ is the sinuosity; $r$ is the inner radius of the apex section; $b$ is the width of the main channel; and $\theta_{\text {geo }}$ is the geometrical angle between the entrance section (CS5) and apex section (CS7). The remaining notations have the same definitions as those in Table 1. 
Table 3 Experimental parameters for vegetated cases ${ }^{\text {a }}$

\begin{tabular}{|c|c|c|c|c|c|c|c|c|c|c|c|}
\hline Source & $\begin{array}{c}S \\
(\%)\end{array}$ & $\begin{array}{c}S_{m c} \\
(\%)\end{array}$ & $s$ & $\begin{array}{c}r \\
(\mathrm{~cm})\end{array}$ & $\begin{array}{c}b \\
(\mathrm{~cm})\end{array}$ & $\begin{array}{c}h \\
(\mathrm{~cm})\end{array}$ & $b / h$ & $\begin{array}{c}H \\
(\mathrm{~cm})\end{array}$ & $\begin{array}{c}h_{v} \\
(\mathrm{~cm})\end{array}$ & $D r$ & $\theta_{\text {geo }}\left({ }^{\circ}\right)$ \\
\hline $\begin{array}{c}\text { MartínVide et al. } \\
(2008)\end{array}$ & 9.4 & 9 & 1.04 & 630 & 40 & 3.8 & 10.5 & 19 & $8 \pm 2$ & 0.8 & 17 \\
\hline $\begin{array}{c}\text { Shiono et al. } \\
(2009)\end{array}$ & 2 & 1.45 & 1.38 & 56.5 & 40 & 4 & 10.0 & 8.9 & $\begin{array}{c}0.7 \pm \\
0.1\end{array}$ & 0.55 & 60 \\
\cline { 2 - 27 } & 2 & 1.45 & 1.38 & 56.5 & 40 & 4 & 10.0 & 7.3 & $\begin{array}{c}0.7 \pm \\
0.1\end{array}$ & 0.45 & 60 \\
\hline $\begin{array}{c}\text { Gunawan et al. } \\
(2008)\end{array}$ & 1 & 0.85 & 1.18 & 470 & 425 & 75 & 5.7 & 75 & - & 0 & 40 \\
\hline
\end{tabular}

${ }^{\mathrm{a}}$ The notations have the same definitions as those in Tables 1 and 2.

Table 4 Height of the secondary current cell in smooth and vegetated meandering compound channels ${ }^{a}$

\begin{tabular}{|c|c|c|c|c|c|c|c|c|}
\hline \multirow{2}{*}{ Case } & \multirow{2}{*}{$D r$} & \multirow{2}{*}{$h_{v}(\mathrm{~cm})$} & \multicolumn{6}{|c|}{$h_{0}(\mathrm{~cm})$} \\
\cline { 4 - 9 } & & & CS1 & CS3 & CS4 & CS5 & CS6 & CS7 \\
\hline MN1 & 0.45 & - & $24.5 \pm 1.5$ & $13.0 \pm 1.5$ & $13.0 \pm 1.5$ & $13.0 \pm 1.5$ & $20.0 \pm 1.5$ & $24.5 \pm 1.5$ \\
\hline MN2 & 0.35 & - & $20.5 \pm 1.5$ & $11.5 \pm 1.5$ & $13.0 \pm 1.5$ & $13.0 \pm 1.5$ & $16.0 \pm 1.5$ & $20.5 \pm 1.5$ \\
\hline MN3 & 0.26 & - & $17.5 \pm 1.5$ & $11.5 \pm 1.5$ & $13.0 \pm 1.5$ & $14.5 \pm 1.5$ & $16.0 \pm 1.5$ & $17.5 \pm 1.5$ \\
\hline MV1 & 0.45 & $2.8 \pm 0.2$ & $24.5 \pm 1.5$ & $14.5 \pm 1.5$ & $16.0 \pm 1.5$ & $16.0 \pm 1.5$ & $20.0 \pm 1.5$ & $24.5 \pm 1.5$ \\
\hline MV2 & 0.35 & $3.5 \pm 0.2$ & $20.5 \pm 1.5$ & $13.0 \pm 1.5$ & $16.0 \pm 1.5$ & $14.5 \pm 1.5$ & $17.5 \pm 1.5$ & $20.5 \pm 1.5$ \\
\hline MV3 & 0.26 & $4.1 \pm 0.2$ & $17.5 \pm 1.5$ & none & $14.5 \pm 1.5$ & $17.5 \pm 1.5$ & $17.5 \pm 1.5$ & $17.5 \pm 1.5$ \\
\hline
\end{tabular}

${ }^{a}$ The notations have the same definitions as those in Table $1 . h_{0}$ is the height of the secondary current cell in each section. The secondary current cell is absent in CS2, so the values of $h_{0}$ are not reported. 
Table 5 Mean depth-averaged flow angle in the meandering main channel along a meander ${ }^{a}$

\begin{tabular}{|c|c|c|c|c|c|c|c|}
\hline \multirow{2}{*}{ Case } & \multicolumn{7}{|c|}{$\theta_{a(m)}(\mathrm{SD})\left(^{\circ}\right)$} \\
\cline { 2 - 8 } & CS1 & CS2 & CS3 & CS4 & CS5 & CS6 & CS7 \\
\hline MN1 & $1.3(1.1)$ & $15.2(0.9)$ & $32.4(2.9)$ & $31.6(2.8)$ & $29.6(1.8)$ & $7.9(0.7)$ & $-1.7(0.4)$ \\
\hline MN2 & $-0.8(0.8)$ & $14.6(1.2)$ & $27.8(1.7)$ & $24.8(2.1)$ & $25.3(2.0)$ & $9.0(1.0)$ & $-2.0(0.8)$ \\
\hline MN3 & $1.7(1.3)$ & $11.7(0.8)$ & $20.2(2.2)$ & $15.0(2.4)$ & $15.7(1.9)$ & $4.4(0.6)$ & $-1.7(1.3)$ \\
\hline MV1 & $2.4(0.6)$ & $14.8(0.6)$ & $24.6(0.8)$ & $20.9(1.1)$ & $21.0(1.8)$ & $8.3(1.2)$ & $-2.8(0.7)$ \\
\hline MV2 & $4.4(0.7)$ & $15.8(0.9)$ & $22.1(2.0)$ & $14.4(1.4)$ & $17.2(2.4)$ & $6.2(1.8)$ & $-2.6(0.8)$ \\
\hline MV3 & $3.9(1.6)$ & $13.9(1.5)$ & $11.5(2.3)$ & $4.4(1.0)$ & $4.7(0.8)$ & $-2.4(1.4)$ & $-4.3(1.8)$ \\
\hline
\end{tabular}

${ }^{\mathrm{a}}$ The mean depth-averaged flow angle $\theta_{a(m)}$ is estimated based on the local angle $\theta_{a}$, i.e., $\theta_{a(m)}=$ $\frac{1}{N} \sum_{1}^{N} \theta_{a}$, where $N$ is the number of $\theta_{a}$ values. Numbers in parentheses are the standard deviations (SD).

Table 6 Summary of the root mean square error (RMSE) in smooth and vegetated channels a

\begin{tabular}{|c|c|c|}
\hline \multirow{2}{*}{ Source } & \multicolumn{2}{|c|}{ RMSE $\left(^{\circ}\right)$} \\
\cline { 2 - 3 } & Smooth channel (CS1 to CS4) & Vegetated channel (CS1 to CS7) \\
\hline Shiono and Muto (1998) & 2.4 & - \\
\hline Muto (1997) & 2.8 & - \\
\hline Shige-Eda et al. (2007) & 1.9 & 4.3 \\
\hline Shiono et al. (2009) & 6.5 & 1.6 \\
\hline MartínVide et al. (2008) & - & 2.6 \\
\hline Gunawan et al. (2008) & - & 3.2 \\
\hline Our study & 3.8 & \\
\hline
\end{tabular}

${ }^{a}$ RMSE is estimated using Eq. (2). 
(a)

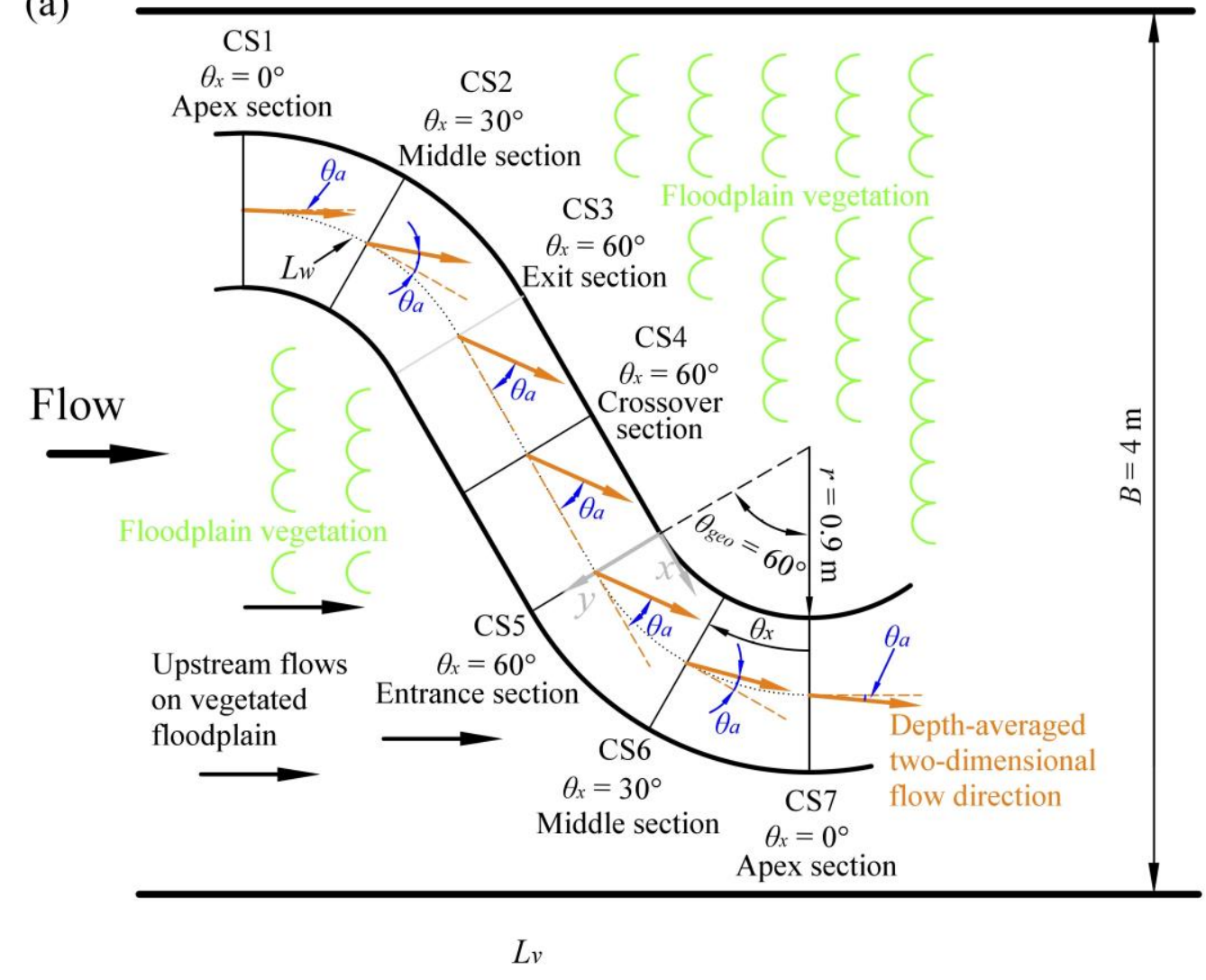

(b)

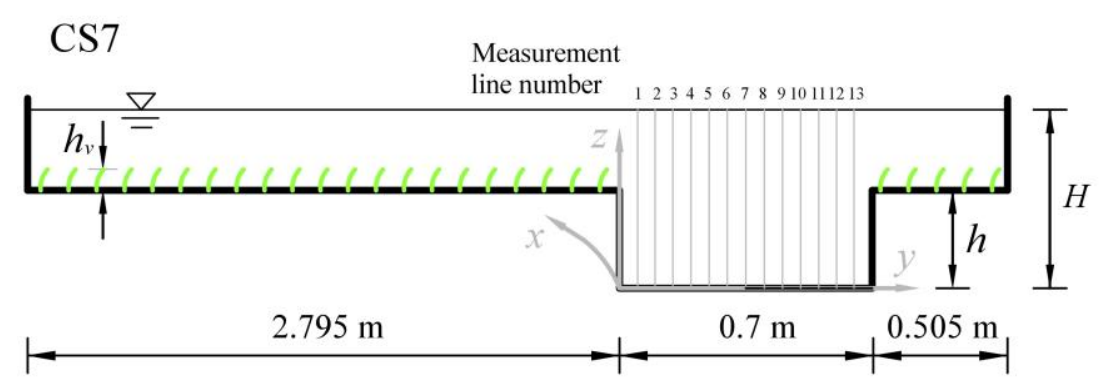

Figure 1 (a) Plan view of the schematic diagram of the vegetated meandering compound channel, (b) Transection of the apex section (CS7, looking downstream). The vegetation is affixed on entire floodplains. CS1, CS2, CS3, CS4, CS5, CS6 and CS7 are the apex section, middle section, exit section, crossover section, entrance section, middle section and apex section, respectively. The depth-averaged two-dimensional flow direction, $\theta_{a}$, is predicted along half a meander. $\theta_{x}$ is the section angle, representing the angle from the apex section to the predictive section (e.g. $\theta_{x}=60^{\circ}$ at CS5) within the meander bend. The geometrical angle between the entrance and apex sections is $\theta_{\text {geo }}\left(=60^{\circ}\right)$. $H$ is the flow depth in the main channel and $h$ is the bankfull level. The measurement lines in the main channel are numbered 1-13. 


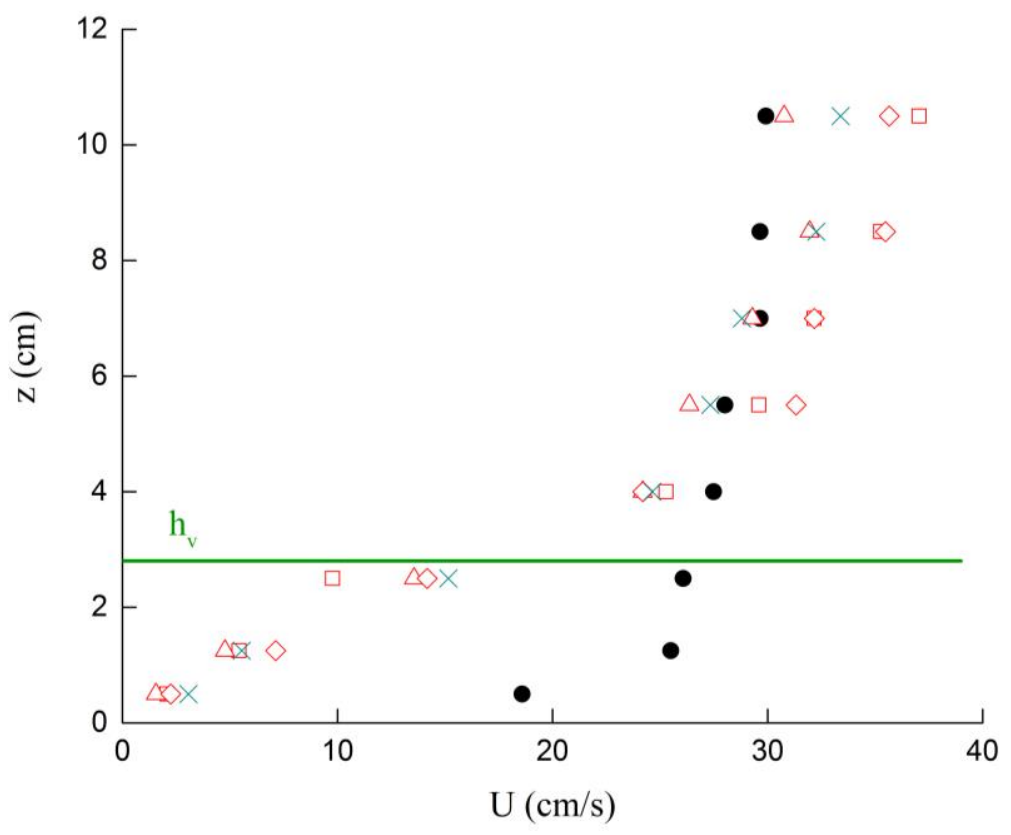

Figure 2 Vertical profiles of time-averaged streamwise velocity $(U)$ at the apex section (CS1) for the smooth floodplain at $y=2.6 \mathrm{~m}$ (solid circles) and the vegetated floodplain at $y=0.4 \mathrm{~m}$ (crosses), $1.8 \mathrm{~m}$ (diamonds), $2.6 \mathrm{~m}$ (triangles) and $3.4 \mathrm{~m}$ (squares) based on the data from MN1 and MV1. The velocity profile of the smooth channel (solid circles) follows a boundary layer profile (logarithmic profile). The solid line indicates the height of the canopy $h_{v}$.

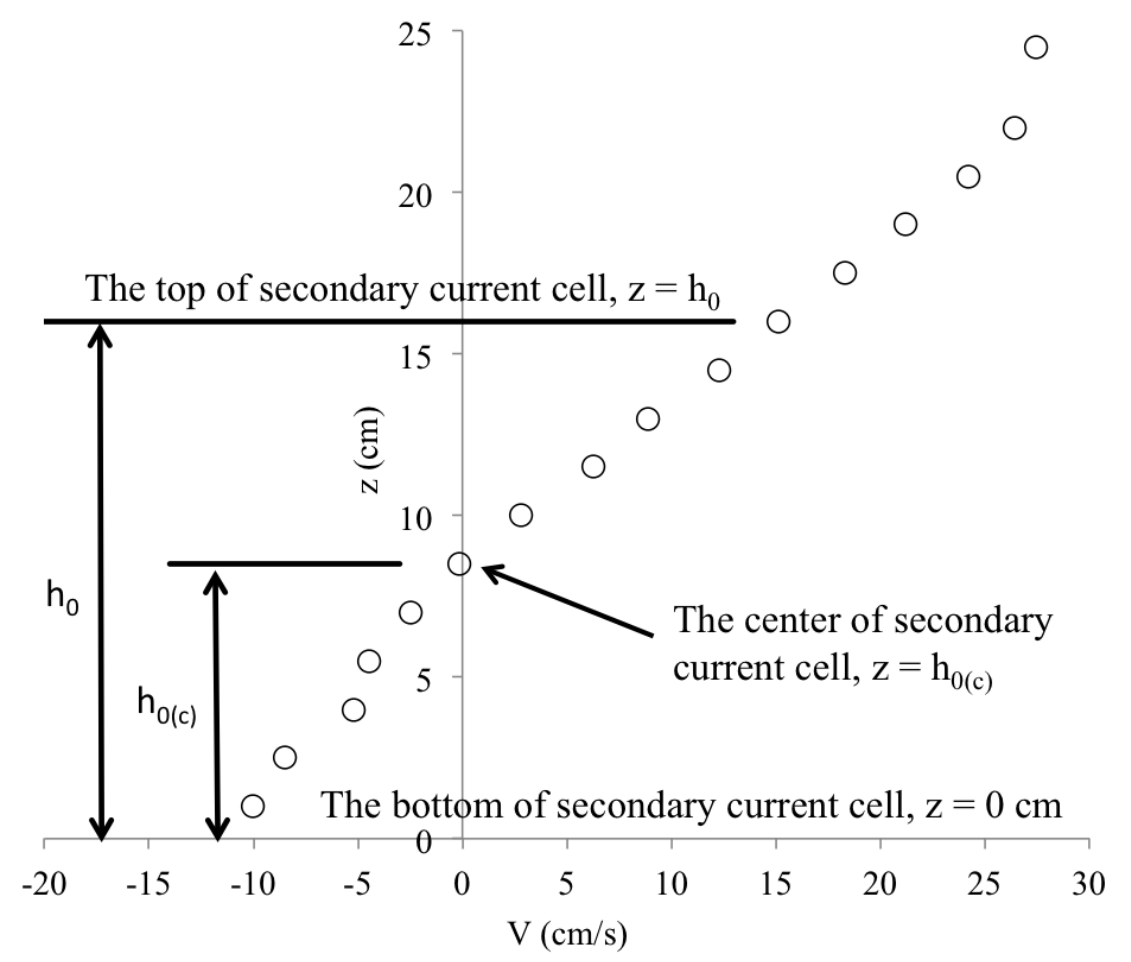

Figure 3 Vertical profile of the time-averaged transverse velocity $(V)$ at the center of the secondary current cell at the entrance section (CS5) based on the experimental data from case MV1. The height of the secondary current cell $\left(h_{0}\right)$ is calculated by $\int_{0}^{h_{0}} V d z=0 . z=h_{0}, z=h_{O(c)}$ and $z=0 \mathrm{~cm}$ indicate the top, the center and the bottom of the secondary current cell, respectively. 

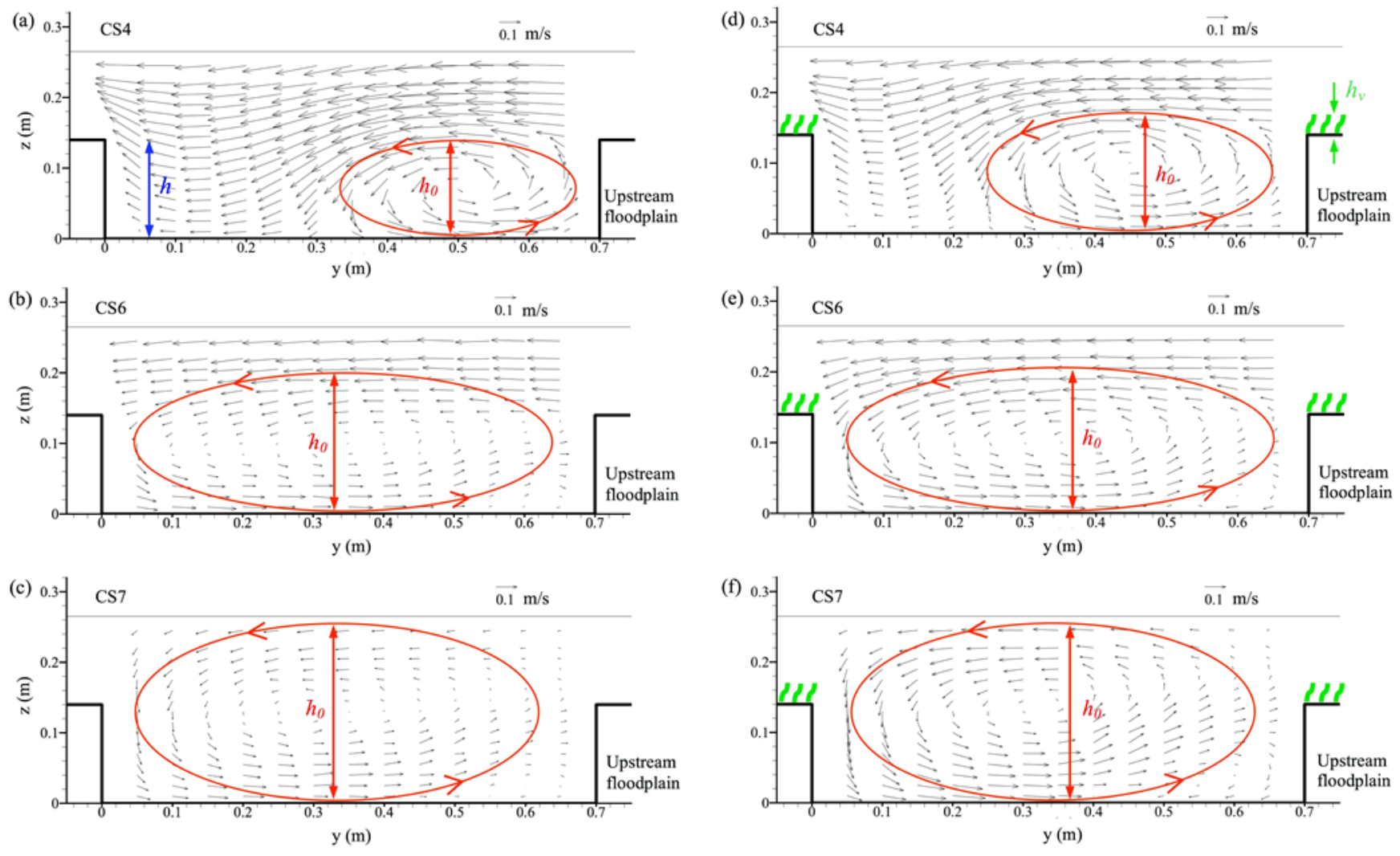

Figure 4 The influence of the floodplain dense vegetation on the height of the secondary current cell $\left(h_{0}\right)$ in three sections of the meandering main channel based on experimental data from the smooth case, MN1, ((a), (b) and (c)) and the vegetated case, MV1 ((d), (e) and (f)). The observed secondary current cells are denoted using circles with arrows at CS4 ((a) and (d)), CS6 ((b) and (e)) and CS7 ((c) and (f)). $h$ is the bankfull level. $\quad h_{v}$ is the vegetation height on the floodplains (right column figures). In each figure, the right wall of the main channel is connected to the upstream floodplain. 


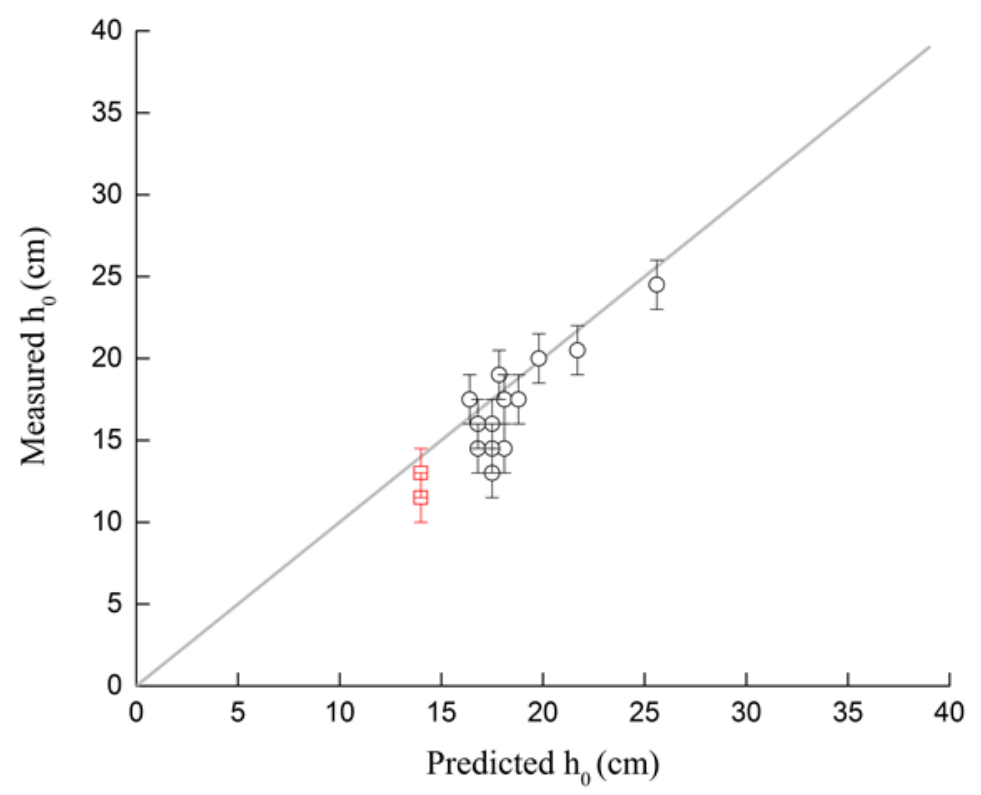

Figure 5 Comparison between the predicted and measured heights of the secondary current cell between the exit section of the previous meander (CS3) and the apex section of the next meander (CS5) based on the data from MN1 to MN3 and MV1 to MV3.

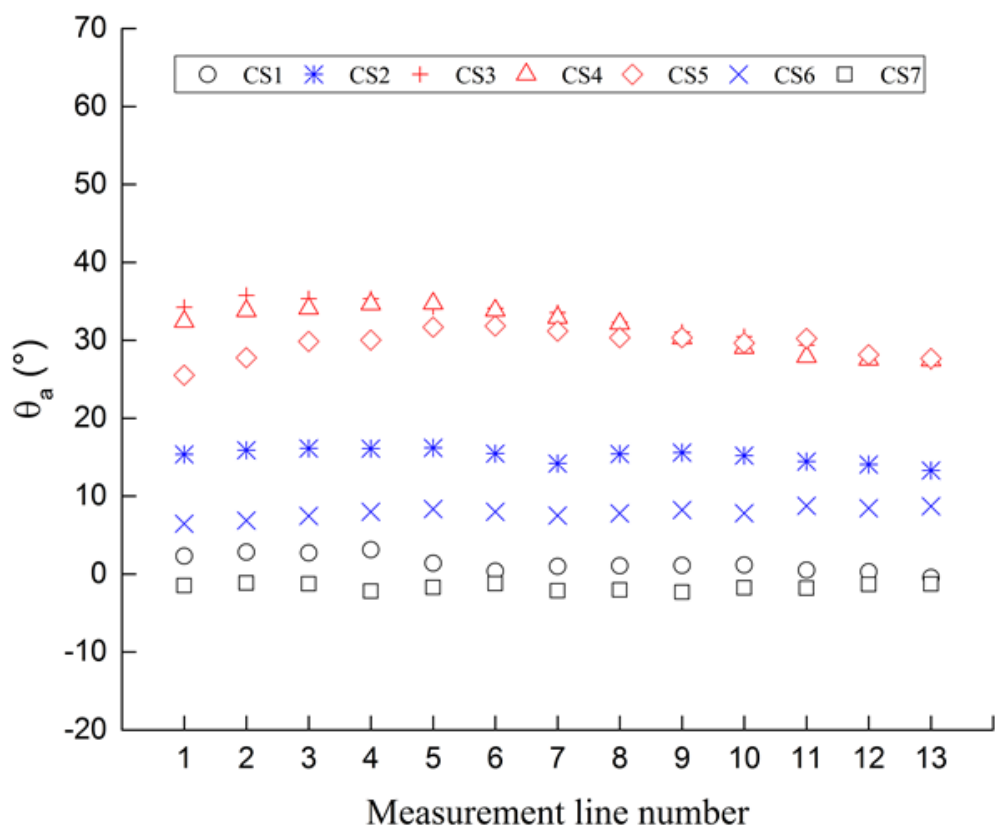

Figure 6 Lateral profiles of the depth-averaged flow angle in the meandering main channel along a meaner based on the data from MN1. The black symbols (OR change to: open circles and squares) indicate $\theta_{a}$ for apex sections (CS1 and CS7) with $\theta_{x}=0^{\circ}$. The blue symbols indicate $\theta_{a}$ for middle sections (CS2 and CS2) with $\theta_{x}=30^{\circ}$. The red symbols indicate $\theta_{a}$ for exit, crossover and entrance sections (CS3, CS4 and CS5, respectively) with $\theta_{x}=60^{\circ}$. 
(a)

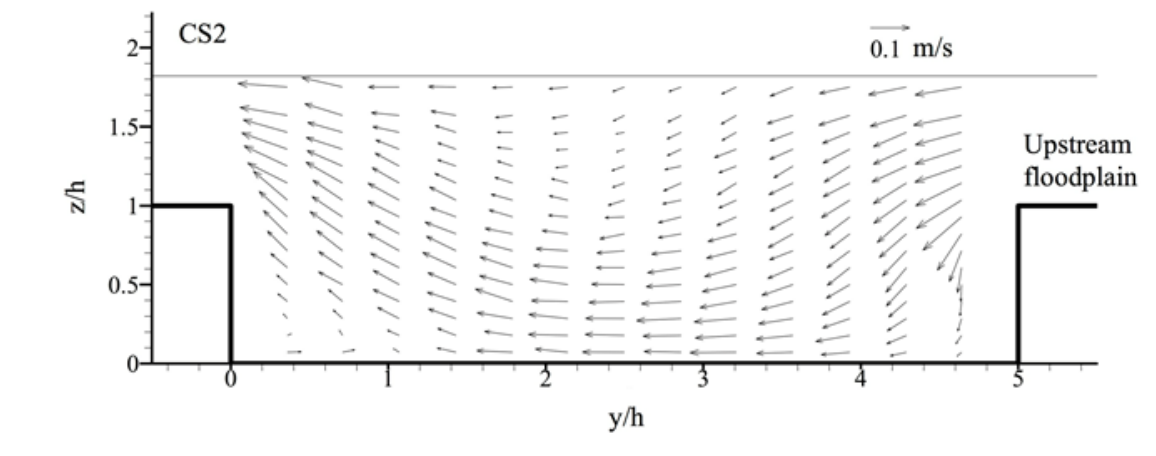

3

4

5

6

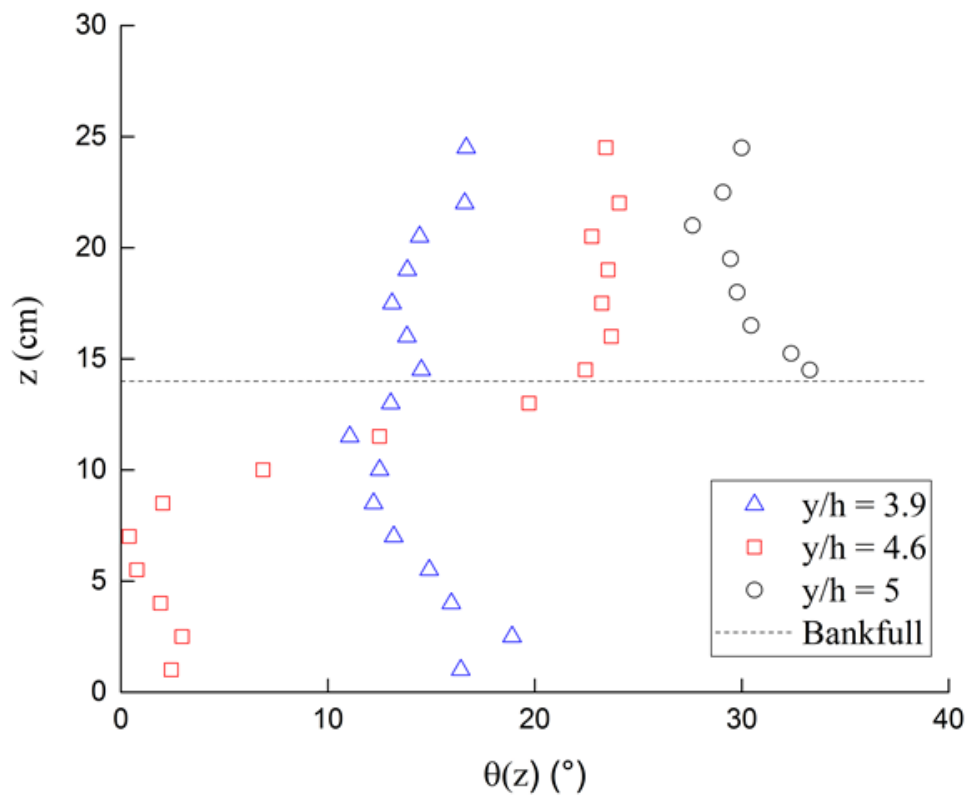

5

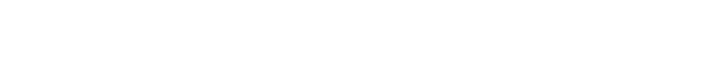

2 


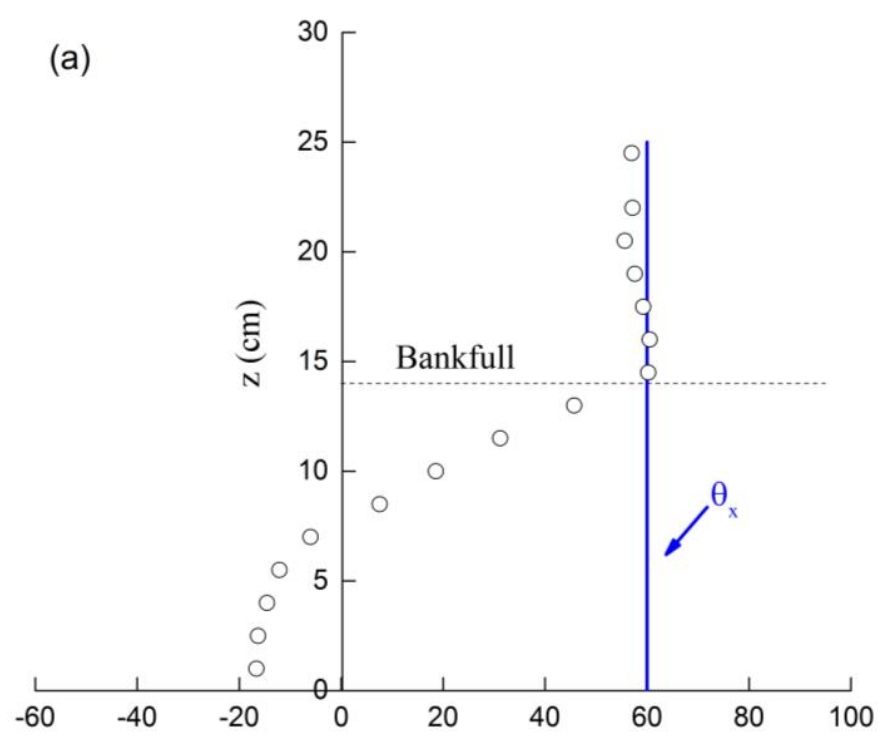

20

(b)
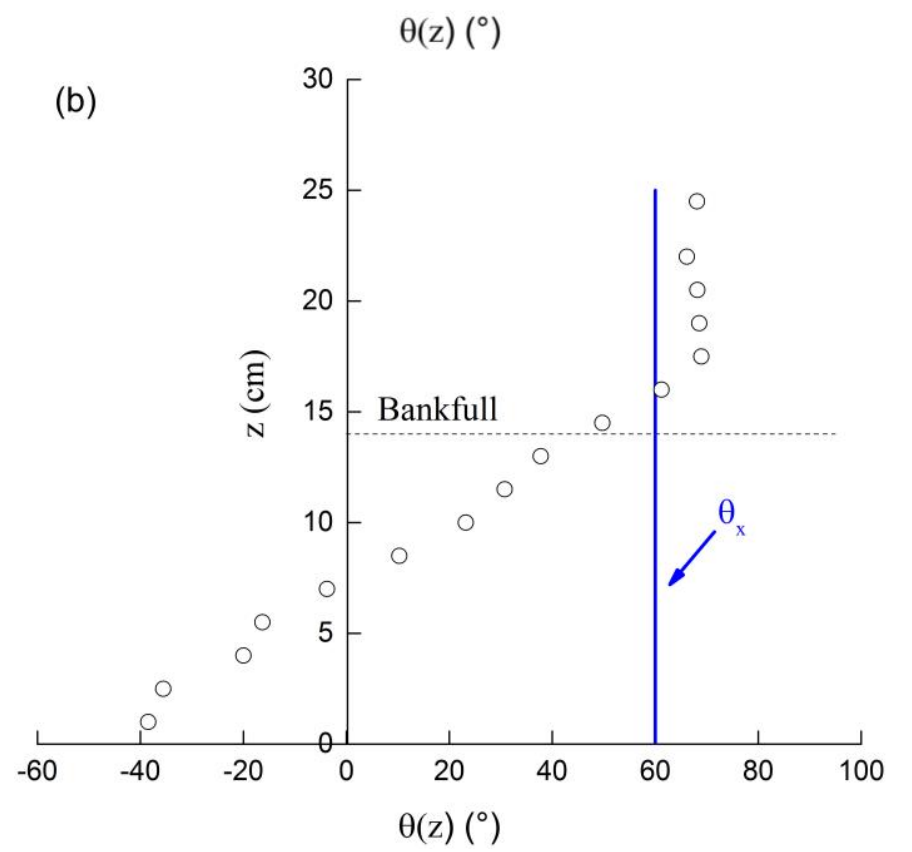

22 Figure 8 Vertical profiles of the local flow angle at (a) the exit section CS3 and (b) the crossover 23 section CS4 based on the data from MN1. $\theta_{x}$ is the section angle, which is $60^{\circ}$ at CS3 and CS4. 


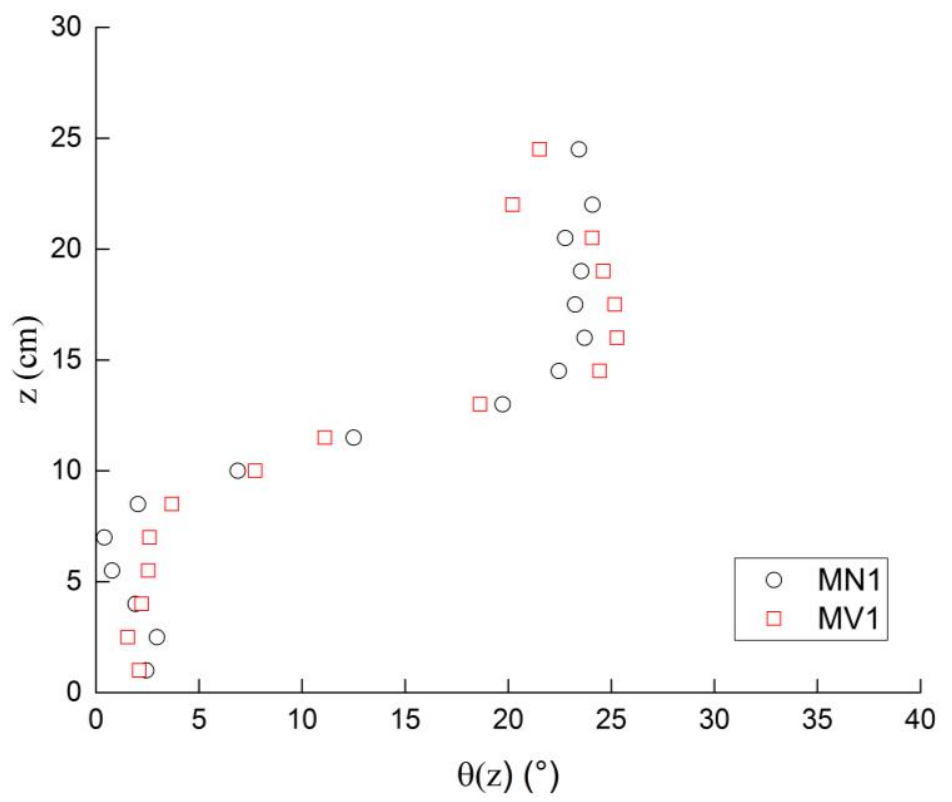

31

32

33

34

35

36
Figure 9 Vertical profiles of local flow angle close to the interface of the main channel and upstream floodplain $(y / h=4.6)$ at CS2 based on the data from MV1 and MN1.
25

26

27

28

29

30

0

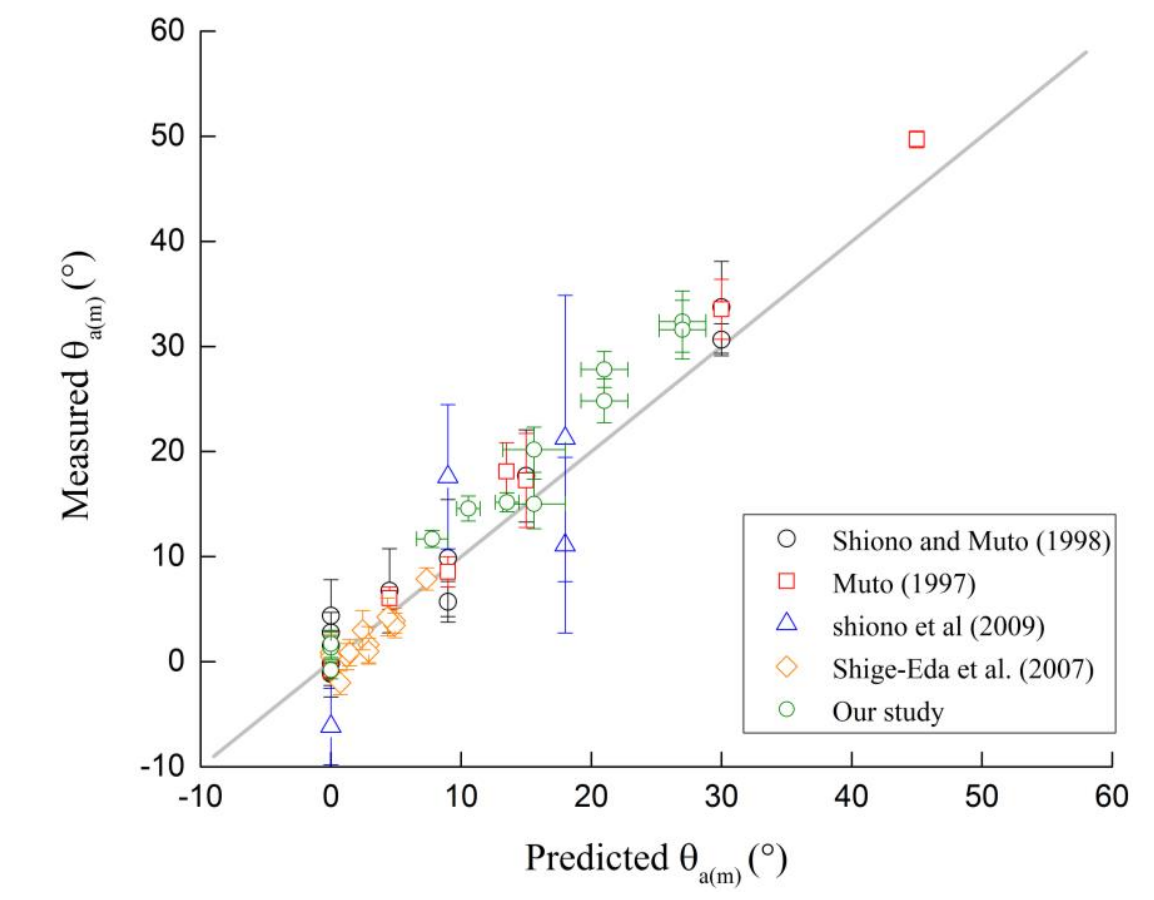

Figure 10 Comparison of the measured and predicted depth-averaged flow angles between the apex section (CS1) and the crossover section (CS4) in smooth channels. The data are taken from Shiono and Muto (1998), Muto (1997), Shiono et al. (2009), Shige-Eda et al. (2007) and this study. The root mean square error (RMSE) is summarized in Table 6. 


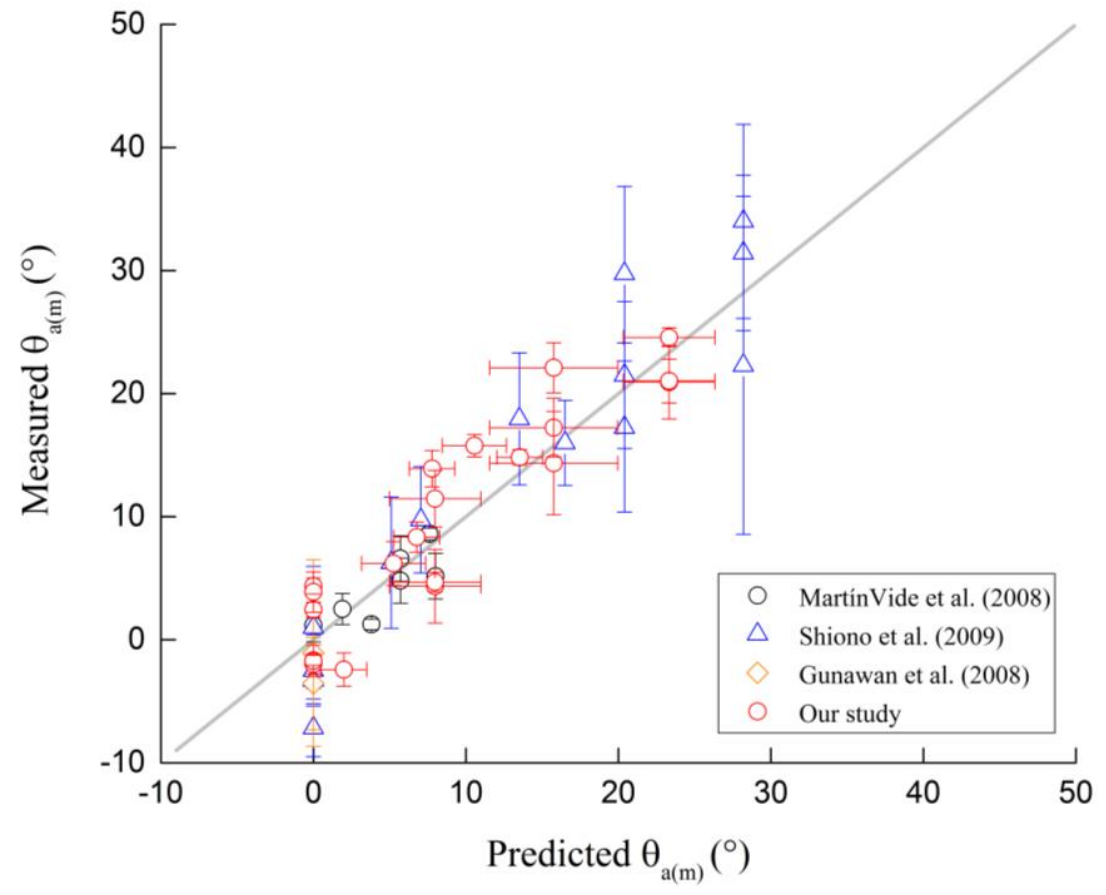

37

38

39

40

41

42

43

44

45

46

47

48
Figure 11 Comparison of the measured and predicted depth-averaged flow angles along half a meander (CS1 to CS7) in vegetated channels. The data are taken from MartínVide et al. (2008), Shiono et al. (2009), Gunawan et al. (2008) and this study. The root mean square error (RMSE) is summarized in Table 6.

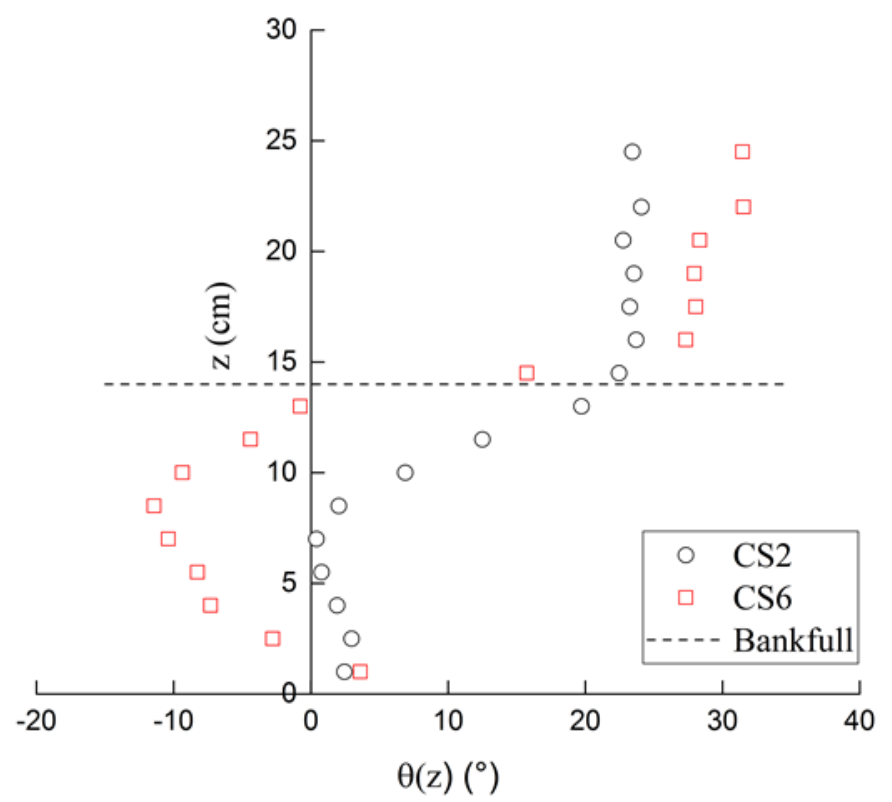

Figure 12 Vertical profiles of the local flow angle at $y / h=4.6$ in CS2 (squares) and CS6 (circles) based on the data from MN1. The horizontal dashed line indicates the bankfull level $h$. 
51

52

53 